\title{
Endocrine side effects of cancer immunotherapy
}

\author{
Priscilla Cukier1, Fernando C Santini'2, Mariana Scaranti² and Ana O Hoff ${ }^{1}$ \\ 1Department of Endocrinology, Instituto do Cancer do Estado de São Paulo, Faculdade de Medicina da Universidade \\ de São Paulo, São Paulo, Brazil \\ 2Department of Oncology, Instituto do Cancer do Estado de São Paulo, Faculdade de Medicina da Universidade de \\ São Paulo, São Paulo, Brazil
}

Correspondence should be addressed to A O Hoff

Email

ana.hoff@hc.fm.usp.br

\begin{abstract}
Immune checkpoint inhibitors have recently become a cornerstone for the treatment of different advanced cancers. These drugs, represented mainly by monoclonal antibodies anti-cytotoxic T-lymphocyte antigen 4 (CTLA-4), anti-programmed cell death protein-1 (PD-1) and anti-PD-1 ligand molecules (PD-L1 and L2), have the ability to reactivate the immune system against tumor cells, but can also trigger a myriad of autoimmune side effects, termed immune-related adverse events (irAEs). In particular, there are a number of endocrine-related irAEs. Current data from clinical trials show increased incidence of hypophysitis with CTLA4 inhibition and thyroid dysfunction with PD-(L)1 blockade. In addition, a few cases of type 1 diabetes mellitus and primary adrenal insufficiency have been reported. We discuss the incidence, clinical manifestations, diagnosis and management of immune-related endocrinopathies in this highly complex context of oncological patients in need of immunotherapies.
\end{abstract}
Key Words
- thyroid
- endocrine side effects
- cancer immunotherapy
hypophysitis
- immune checkpoint inhibitors

\section{Introduction}

In the past few decades, cancer therapy has advanced, with immuno-oncology emerging as an effective strategy for a variety of advanced-stage cancers (Horvat et al. 2015). There are a number of modalities of immunotherapy, including monoclonal antibodies (mAbs), adoptive cell therapy, immunomodulatory small molecules, oncolytic viruses, vaccines and tumor-targeting mAbs. As a whole, immunotherapy has the potential to generate or augment an immune response against cancers, offering a robust and durable response.

Most incipient tumors are eliminated by a process called immune surveillance. Cancer cells, however, can evade this immune attack through the upregulation of immune-inhibitory pathways. Immunotherapy works to suppress these immune checkpoints resulting in immunemediated antitumor activity.
Clinical development and approval of immune checkpoint inhibitors have transformed the natural history of certain tumors. Several immune checkpoint inhibitors are already approved for treatment of different cancers by the United States Food and Drug Administration (FDA) including melanoma, non-small cell lung cancer (NSCLC), head and neck cancer, renal cell carcinoma, urothelial cancer, Merkel cell carcinoma, Hodgkin's lymphoma and mismatch-repair deficient cancers (Table 1). Of note, combination of anti-CTLA4 and anti-PD- 1 is approved for cutaneous melanoma, and promising results from early phase trials have been published for other malignancies (Antonia et al. 2016, Hellmann et al. 2017).

Given that immune-inhibitory pathways have an important role in the maintenance of self-tolerance, therapeutic targeting of these pathways can lead to

This paper is part of a special section on Immunotherapy and Cancer.

The guest editors for this section were Joanne Y Y Ngeow and Laura S Ward Downloaded from Bioscientifica.com at 04/26/2023 01:03:28PM 
Table 1 Immunotherapy monoclonal antibodies and their main indications.

\begin{tabular}{|c|c|c|c|c|c|c|}
\hline & \multicolumn{2}{|c|}{ Anti-PD-1 } & \multicolumn{3}{|c|}{ Anti-PD-L1 } & \multirow{2}{*}{$\begin{array}{c}\text { Anti-CTLA4 } \\
\text { Ipilimumab }\end{array}$} \\
\hline & Nivolumab & Pembrolizumab & Atezolizumab & Durvalumab & Avelumab & \\
\hline Melanoma & & & $\mathrm{X}$ & $\mathrm{X}$ & $\mathrm{x}$ & \\
\hline NSCLC & & & & $\mathrm{X}$ & $x$ & $x$ \\
\hline HNSCC & & & $\mathrm{X}$ & $\mathrm{X}$ & $\mathrm{x}$ & $\mathrm{X}$ \\
\hline $\mathrm{RCC}$ & & $x$ & $\mathrm{x}$ & $\mathrm{x}$ & $\mathrm{x}$ & $\mathrm{X}$ \\
\hline Urothelial & & & & & & $x$ \\
\hline $\mathrm{CHL}$ & $\mathrm{X}$ & & $x$ & $x$ & $x$ & $x$ \\
\hline MSI-H & $\mathrm{X}$ & & $X$ & $\mathrm{X}$ & $\mathrm{X}$ & $\mathrm{X}$ \\
\hline Merkel cell carcinoma & $\mathrm{X}$ & $x$ & $\mathrm{X}$ & $\mathrm{X}$ & & $\mathrm{X}$ \\
\hline
\end{tabular}

CHL, classical Hodgkin's lymphoma; HNSCC, head and neck squamous cell carcinoma; MSI-H, high microsatellite instability tumors; NSCLC, non-small cell lung cancer; RCC, renal cell carcinoma.

imbalances in immunologic tolerance, which manifest as immune-related adverse events (irAEs). A broad range of autoimmune toxicities have been reported, and nearly all organs can be affected, including skin, gastrointestinal tract, lung, kidney and heart, among others (Michot et al. 2016). Even immune-privileged organs such as the eye and the brain can be affected (Crews et al. 2015, Henderson et al. 2015, Yeh et al. 2015, Bossart et al. 2017). The incidence of any grade irAEs is reported to range from 15 to $90 \%$ in single agent trials (Hodi et al. 2010, Eggermont et al. 2016, Ferris et al. 2016, Kumar et al. 2017). The spectrum of autoimmune adverse events is different in the anti-CTLA4- and anti-PD-L1-treated patients. For example, thyroid diseases are more frequent with PD-1 blockade, whereas colitis and hypophysitis are more frequent with CTLA-4 blockade.

Ipilimumab, the main representative of CTLA-4 inhibitors, has been extensively studied. The incidence of irAEs is dose related, the most common ones are pruritus, diarrhea, rash, and fatigue. Grade 3-4 (severe to life-threatening) (http://evs.nci.nih.gov/ftp1/CTCAE) irAEs were reported in less than $5 \%$ of patients, except for diarrhea (Weber 2009, Hodi et al. 2010, Boutros et al. 2016).

Nivolumab and pembrolizumab, the best studied anti-PD-1 drugs so far, have very similar safety profiles and induce fewer adverse events than ipilimumab. The most common adverse events of any grade following treatment with anti-PD-1 therapy included fatigue, rash, pruritus and diarrhea. Potential irAEs of any grade affected primarily the skin, gastrointestinal, endocrine and pulmonary systems and were generally of a low grade. Grade 3-4 irAEs occurred in $2-3 \%$ of patients and were generally managed with withholding the drug, corticosteroids use or permanent discontinuation of the agent. In general, grade 1-2 (asymptomatic to moderate) (http://evs.nci.nih.gov/ftp1/CTCAE) adverse events are managed symptomatically and usually do not require dose omission and discontinuation (Friedman et al. 2016).

In contrast to inhibiting PD-1, targeting PD-L1 leaves PD-L2 uninhibited, which may preserve a component of peripheral immune homeostasis. For organs like the lung, this was hypothesized to reduce the likelihood of developing severe inflammatory toxicity (Rozali et al. 2012). However, a recent study by Pillai and coworkers investigating 4869 patients with NSCLC treated with either PD-1 or PD-L1 inhibitors showed no significant difference in toxicity profile between them (Pillai et al. 2016).

Recent clinical trials investigating combination therapy with CTLA- 4 and PD-(L) 1 blockade has shown promising results; however, it has been associated with a higher prevalence of irAEs than monotherapy. Grade 3 or 4 adverse events were reported in up to $55 \%$ of the patients, in particular diarrhea, colitis and elevated aminotransferase levels (Hodi et al. 2015, Larkin et al. 2015).

Approximately one-quarter to one-third of the patients treated with checkpoint blockade will receive immunosuppressive therapy for the management of irAE. Data published with melanoma patients also report that overall survival and time to treatment failure were not affected by the occurrence of irAEs or the need for systemic corticosteroids (Horvat et al. 2015). Most irAEs occur within 3-6 months of initiation of immunotherapy, although a delayed effect of immune checkpoint antibodies cannot be ruled out, sometimes up to few years after the start of treatment (Michot et al. 2016).

Whether irAEs are associated with improved response of tumors to immune checkpoint blockade is still not understood, due to conflicting data. A large meta-analysis of multiple melanoma immunotherapy modalities found that development of vitiligo is associated with better progression-free survival and overall survival,

Published by Bioscientifica Ltd 
HYPOPHYSITIS

(suggestive symptoms: severe fatigue, headache)

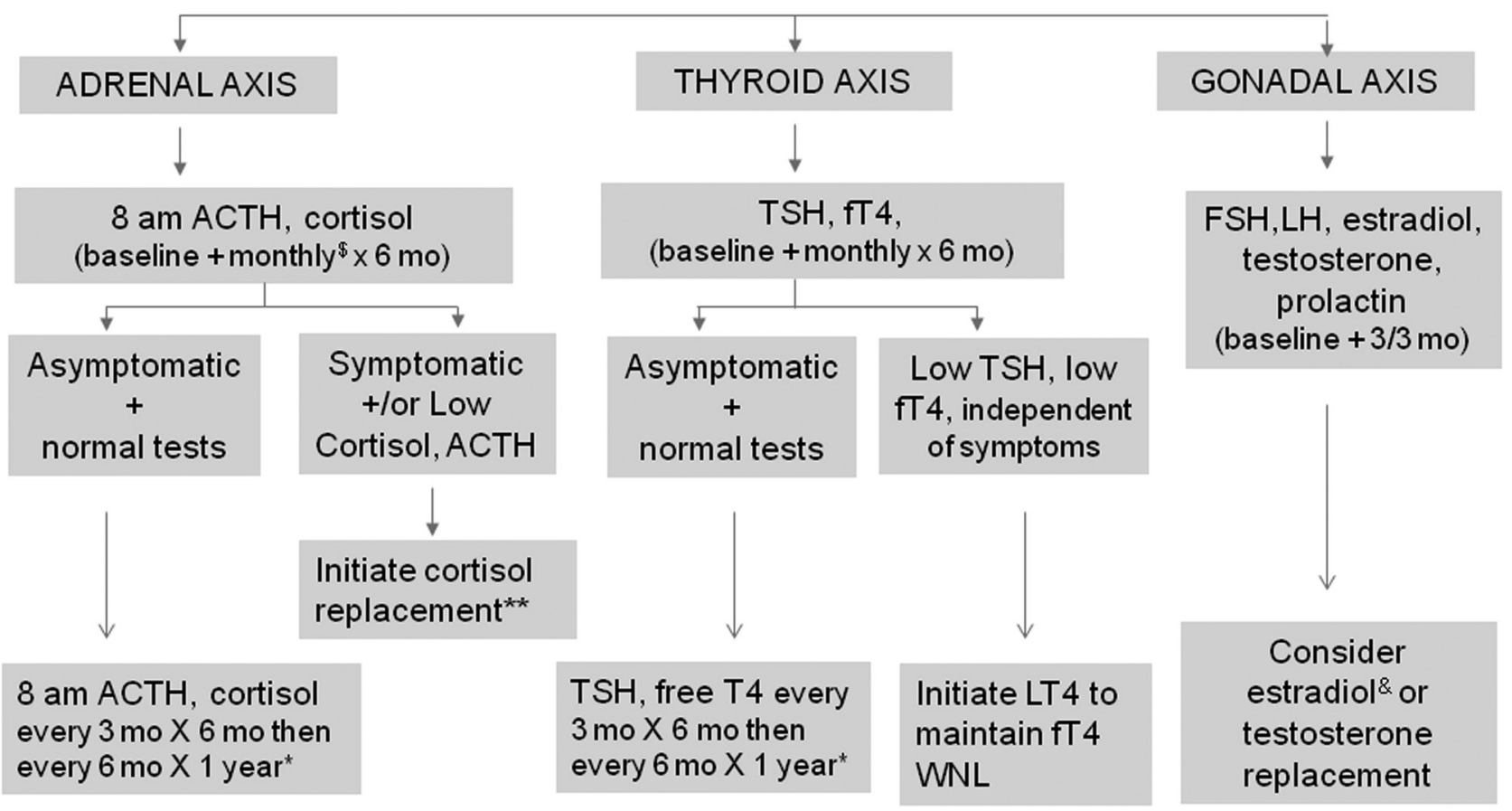

Figure 1

Suggested recommendation for biochemical evaluation and monitoring of pituitary dysfunction in patients treated with immunotherapy. \$When using anti-CTLA4, anti-PD-(L)1 baseline and if symptoms persist on * 2 years of follow-up, **high-dose steroids in patients with critical illness, in patients with severe hyponatremia, severe headache, visual abnormalities from pituitary enlargement and low-dose steroids (e.g. hydrocortisone 20-30 mg/day) with mild symptoms such as fatigue, mild headache. \&Should be considered to selected premenopausal women. ACTH, adrenocorticotrophic hormone;

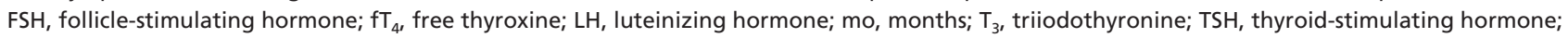
WNL, within normal range.

with a twofold to fourfold reduction in risk of disease progression and death in patients who develop vitiligo. This trend might be due to the monitoring of patients for a longer period of time and bias resulting from extended duration of symptomatic observation (Lo et al. 2015, Teulings et al. 2015).

The aim of this review is to describe the endocrinerelated adverse events associated with immunotherapies, focused on anti-CTLA-4, anti-PD-1 and anti-PD-L1, as well as to discuss their management and suggested evaluation for early diagnosis (Fig. 1). As symptoms of endocrinopathies could be nonspecific, a high degree of suspicion should be in place so that diagnosis could be confirmed and treatment could be rapidly instituted.

\section{Brief review of the immunobiology of cancer}

There are three necessary steps to mount an effective antitumor immune response: dendritic cells antigen presentation, production of protective $\mathrm{T}$ cell response in the central lymphatic system and overcoming immunosuppression in the tumor microenvironment.

The initial activation of naïve $\mathrm{T}$ lymphocytes occurs mainly in secondary lymphoid organs, where they may encounter antigens presented by mature dendritic cells. The specific recognition of antigenic peptides, presented by the MHC, triggers TCR signaling. The co-stimulatory and co-inhibitory receptors on $\mathrm{T}$ cells direct $\mathrm{T}$ cell function and determine $\mathrm{T}$ cell fate. The best characterized central co-stimulatory pathway in $\mathrm{T}$ cell activation is represented by the engagement of CD28 with B7-1 (CD80) and B7-2 (CD86), expressed on activated antigen-presenting cells (APCs). In resting T cells, CTLA-4 binds with high affinity to B7 and can compete with CD28 to further inhibit T cell activity. This process stops the $\mathrm{T}$ cell from maintaining an immune response. Monoclonal antibodies (mAb) that target CTLA-4 reinvigorate proliferation of T cells, which become constitutively active.

Activated $\mathrm{T}$ cells will exit the lymph node and enter the tumor bed where a myriad of immunosuppressive

Published by Bioscientifica Ltd. 
mechanisms coexist, represented mainly by upregulation of PD-L1 and PD-L2 on cancer cell surface. PD-1 is expressed on the surface of activated $\mathrm{T}$ and $\mathrm{B}$ lymphocytes and monocytes. Binding of PD-1 to its ligands, PD-L1 and PD-L2, inhibits the immune response. A $\mathrm{mAb}$ against PD-1 or PD-L1 can block this pathway and result in the upregulation of immune response and inhibition of tumor growth. Furthermore, anti-CTLA-4 mAbs might exert some of its antitumor effect in the tumor microenvironment with depletion of the $\mathrm{T}_{\text {REG }}$ cell population (Latchman et al. 2001, Chen et al. 2012, Boussiotis 2016).

As CTLA-4 and PD-1 regulate the immune response at different levels, one might expect that the incidence and type of the irAEs are different between anti-CTLA-4 and anti-PD-L1. Likewise, autoimmune manifestations of animals with PD- 1 or CTLA- 4 deficiencies are distinct (Francisco et al. 2010, Klocke et al. 2016). CTLA-4 regulates $\mathrm{T}$ cell activation centrally and potentially in all lymph nodes. This broad activation explains the higher frequency of irAEs after CTLA-4 blockade when compared to other checkpoint inhibitors. Of note, polymorphisms of $P D-1$ and CTLA-4 are associated with various autoimmune conditions such as rheumatoid arthritis, Addison disease, celiac disease, Crohn's disease, thyroid disorders and type 1 diabetes (Ueda et al. 2003).

\section{Immunotherapy-induced endocrine toxicities}

Fatigue is the most frequent adverse event with immune check point blockade. Its intensity, however, is usually mild and the presence of severe fatigue should trigger an assessment for underlying disorders, such as endocrinopathies.

The spectrum of endocrine irAEs includes hypopituitarism caused by hypophysitis, primary or secondary thyroid disease, primary or secondary adrenal insufficiency, hyperglycemia due to type 1 diabetes and, more rarely, hypoparathyroidism (Table 2). The precise frequency and severity of endocrine dysfunction is not well defined, due to variations in data collection. Initially, clinical trial reports of adverse events were based on symptoms, which could be nonspecific, rather than a biochemically defined diagnosis. More recent trials, however, have increasingly introduced hormonal

Table 2 Reported frequencies of endocrine immune-related adverse events observed with immunotherapies.

\begin{tabular}{|c|c|c|c|c|c|}
\hline \multirow[b]{2}{*}{ Monoclonal antibodies } & \multicolumn{5}{|c|}{ Endocrinopathies } \\
\hline & Hypophysitis (\%) & Hypothyroidism (\%) & Hyperthyroidism (\%) & $\begin{array}{l}\text { Primary adrenal } \\
\text { insufficiency }(\%)\end{array}$ & Type 1 DM (\%) \\
\hline \multicolumn{6}{|l|}{ Anti-CTLA-4 } \\
\hline Ipilimumaba & $1.5-17$ & $1.5-6.8$ & 4 & $0.8-1.6$ & NR \\
\hline Tremelimumabb & $0.4-2$ & 2.3 & $0-3$ & 1 & NR \\
\hline \multicolumn{6}{|l|}{ Anti-PD-1 } \\
\hline Nivolumabc & $0.6-1.5$ & $9-10.8$ & 2.7 & 1 & 0.9 \\
\hline Pembrolizumabd & $0.6-1$ & $7-9.1$ & $3.4-7.8$ & NR & 0.2 \\
\hline \multicolumn{6}{|l|}{ Anti-PD-L1 } \\
\hline Avelumabe & NR & 5 & 0.4 & 0.5 & 0.1 \\
\hline Atezolizumabf & 0.2 & $2.5-4.2$ & $0.6-1.1$ & 0.4 & $0.2-0.3$ \\
\hline Durvalumabg & $<0.1$ & $5.5-9.6$ & $4.9-5.7$ & $0.5-0.9$ & 0.1 \\
\hline \multicolumn{6}{|l|}{ Combined therapy } \\
\hline Nivolumab + ipilimumabh & $4-12.8$ & $4-27$ & $4.3-14$ & $4-8 *$ & NR \\
\hline Pembrolizumab + ipilimumabi & 9.1 & $6-13.6$ & $4.5-6$ & $6 *$ & NR \\
\hline Durvalumab + tremelimumabj & NR & 5.9 & NR & NR & NR \\
\hline \multicolumn{6}{|c|}{$\begin{array}{l}\text { *Comprises primary and secondary adrenal insufficiency. } \\
\text { CTLA-4, cytotoxic T-lymphocyte antigen 4; PD-1, programmed cell death protein-1; PD-L1, PD-1 ligand molecule; NR, not reported. } \\
\text { aPhan et al. 2003, Attia et al. 2005, Maker et al. 2006, Downey et al. 2007, Yang et al. 2007, Weber et al. 2008, 2009, 2017, Ansell et al. 2009, Hodi et al. } \\
\text { 2010, Ku et al. 2010, O'Day et al. 2010, Royal et al. 2010, Wolchok et al. 2010, Di Giacomo et al. 2011, Hersh et al. 2011, Sarnaik et al. 2011, Margolin } \\
\text { et al. 2012, Altomonte et al. 2013, Slovin et al. 2013, Chiarion-Sileni et al. 2014, Kwon et al. 2014, Ryder et al. 2014, Larkin et al. 2015, Postow et al. 2015, } \\
\text { Eggermont et al. 2016; 'Ribas et al. 2005, Camacho et al. 2009, Chung et al. 2010, Kirkwood et al. 2010, Ralph et al. 2010, Ribas et al. 2012, 2013, } \\
\text { Sangro et al. 2013, Aglietta et al. 2014, Calabrò et al. 2015; 'Brahmer et al. 2010, Topalian et al. 2012, Weber et al. 2013, 2015a, b, 2017, Topalian et al. } \\
\text { 2014, Ansell et al. 2015, Bauer et al. 2015, Brahmer et al. 2015, El-Khoueiry et al. 2015, Gettinger et al. 2015, Hamanishi et al. 2015, Motzer et al. 2015, } \\
\text { Nishio et al. 2015, Paz-Ares et al. 2015, Rizvi et al. 2015b, Robert et al. 2015a; dHamid et al. 2013, Robert et al. 2014, Doi et al. 2015, Garon et al. 2015, } \\
\text { Le et al. 2015, Ott et al. 2015, Ribas et al. 2015, Robert et al. 2015b, Varga et al. 2015, Reck et al. 2016, Seiwert et al. 2016; } \text { Disis et al. 2015, Gulley et al. } \\
\text { 2015, Kelly et al. 2015, Shitara et al. 2015, Yamada et al. 2015; } \text { Cho et al. 2013, Hamid et al. 2013, Herbst et al. 2013, Spigel et al. 2013, Powles et al. } \\
\text { 2014, Petrylak et al. 2015, Spira et al. 2015; gLutzky et al. 2014, Segal et al. 2014, 2016, lguchi et al. 2015, Rizvi et al. 2015a; hWolchok et al. 2013, } \\
\text { Antonia et al. 2015a,b, Hammers et al. 2015, Hodi et al. 2015, Larkin et al. 2015, Postow et al. 2015; 'Atkins et al. 2015, Patnaik et al. 2015; } \\
\text { jAntonia et al. 2015a,b. }\end{array}$} \\
\hline $\begin{array}{l}\text { http://erc.endocrinology-journals.org } \\
\text { DOI: 10.1530/ERC-17-0358 }\end{array}$ & $\begin{array}{r}\text { (C) } 2018 \text { Society for } \\
\text { Printed } \mathrm{i}\end{array}$ & $\begin{array}{l}\text { docrinology } \\
\text { Great Britain }\end{array}$ & by Bioscientifica Ltd. & & \\
\hline
\end{tabular}


screening, resulting in earlier and more accurate diagnoses (Corsello et al. 2013).

Hypophysitis and hypothyroidism are the most common endocrinopathies, seen in up to $10 \%$ of patients treated with anti-CTLA-4 and anti-PD-1/ PD-L1 antibodies (Corsello et al. 2013, Topalian et al. 2014, O'Donnell et al. 2015, Eggermont et al. 2016, González-Rodríguez et al. 2016, Byun et al. 2017). The growing recognition that immunotherapy is potentially associated with endocrine-related adverse events has resulted in higher reported rates of hypophysitis, as clinical suspicion and routine laboratory testing have become a more routine practice (Albarel et al. 2015, Min et al. 2015, Faje 2016). Clinical suspicion and routine hormone testing are key to the diagnosis of immunerelated endocrinopathies.

\section{Pituitary dysfunction}

\section{Anti-CTLA-4 mAbs}

Pituitary dysfunction is among the most commonly reported endocrinopathies and is much more common after anti-CTLA-4 therapy than other immunotherapies (Table 2). The average incidence of ipilimumab-induced hypophysitis is $13 \%$, ranging from 1.5 to $17 \%$ (Tables 2 and 3) (Faje et al. 2014, Faje 2016). In contrast to lymphocytic autoimmune hypophysitis, ipilimumabinduced hypophysitis occurs more frequently in men (Corsello et al. 2013, Min et al. 2015, Faje et al. 2016) and in those of an older age (Faje et al. 2014, Faje 2016), even after adjustment of melanoma incidence in male and the elderly. Other associated agents and radiotherapy can alter the risk of hypophysitis induced by ipilimumab, but data are limited (Postow et al. 2012, Stamell et al. 2013, Shahabi et al. 2015).

The time to occurrence of these endocrine abnormalities has not been routinely reported in these trials. Notwithstanding, the average time to diagnosis of hypophysitis is 9 weeks of initiation of ipilimumab. A homogeneous or heterogeneous enlargement of the pituitary with thickening of the stalk, seen at pituitary magnetic resonance imaging (MRI), is a sensitive and specific indicator of hypophysitis. These radiographic changes may be the first sign of hypophysitis, preceding hormonal disturbances and symptoms (van der Hiel et al. 2013, Faje et al. 2014). Pituitary enlargement can be mild and only apparent if compared with previous imaging study and reduces rapidly after glucocorticoid initiation in virtually all patients (Table 3 ).
Table 3 Ipilimumab-induced pituitary dysfunction - clinical and laboratory characteristics from three longitudinal cohorts (Faje et al. 2014, Albarel et al. 2015, Min et al. 2015).

\begin{tabular}{|c|c|}
\hline & No. $(\%)$ \\
\hline Patients & $428(100)$ \\
\hline Hypophysitis & $57(13.3)$ \\
\hline Male & $44(77)$ \\
\hline $\begin{array}{l}\text { Median time to diagnose after Ipilimumab } \\
\text { initiation (weeks) }\end{array}$ & 9 \\
\hline Pituitary enlargement & $44(78)$ \\
\hline Visual disturbances & $0(0)$ \\
\hline \multicolumn{2}{|l|}{ Symptoms } \\
\hline Headache & $27(84)$ \\
\hline Fatigue & $21(65)$ \\
\hline \multicolumn{2}{|l|}{ Laboratory abnormalities at diagnosis } \\
\hline Hyponatremia & $22(56)$ \\
\hline Thyroid & $52(92)$ \\
\hline Adrenal & $40(74)$ \\
\hline Gonadal & $42(85)$ \\
\hline Growth hormone (IGF-1) & $6(28)$ \\
\hline \multicolumn{2}{|l|}{ Prolactin } \\
\hline High & $2(6)$ \\
\hline Low & $29(94)$ \\
\hline Diabetes insipidus & $0(0)$ \\
\hline Resolution of pituitary enlargement & $40(100)$ \\
\hline \multicolumn{2}{|l|}{ Resolution of secondary hormonal abnormalities } \\
\hline Thyroid & $34(59)$ \\
\hline Adrenal & $8(14)$ \\
\hline Gonadal & $35(59)$ \\
\hline Growth hormone (IGF-1) & $10(90)$ \\
\hline Prolactin & $10(90)$ \\
\hline
\end{tabular}

The most frequent symptoms of ipilimumab-induced hypophysitis are headache and fatigue. In contrast to lymphocytic hypophysitis, visual disturbances are rare. Despite the fact that most patients will present multiple hormone deficiencies, central hypothyroidism and secondary adrenal insufficiency remain most common, while both growth hormone and prolactin axis are generally spared. Secondary hyponatremia due to adrenal insufficiency and central hypothyroidism is frequently observed, but diabetes insipidus is rarely present. Reduction of TSH levels, indicating incipient central hypothyroidism, often occurs prior to the diagnosis of hypophysitis (Faje et al. 2014). Secondary adrenal insufficiency associated with anti-CTLA-4-related hypophysitis is usually permanent and requires lifelong steroid replacement (Albarel et al. 2015) (Table 3). Some studies suggest that the development of hypophysitis may predict a better antitumor response of ipilimumab (Faje et al. 2014).

Iwama and coworkers established a murine model of secondary hypophysitis based on injections of a CTLA-4-blocking antibody (Iwama et al. 2014). CTLA-4 is expressed in pituitary endocrine cells, predominantly

Published by Bioscientifica Ltd. 
in prolactin- and TSH-secreting cells. The study reported that blocking CTLA-4 expression in these pituitary endocrine cells with a specific mAb led to site-specific deposition of complement components, pituitary infiltration and antibody formation. The antibodies recognized predominantly TSH-secreting cells and, less frequently, FSH- or ACTH-secreting cells (Iwama et al. 2014).

Overall, hypophysitis is caused by a type II hypersensitivity reaction in which the CTLA-4 antibody binds to the cognate antigen expressed on pituitary cells, activates complement and promotes gland destruction (Laurent et al. 2013, Iwama et al. 2014, Kuehn et al. 2014, Schubert et al. 2014, Romano et al. 2015). Conversely, patients treated with PD-1 or PD-L1 IgG4 mAb, which are less effective for antibody-dependent cell-mediated cytotoxicity (ADCC), rarely develop pituitary damage (Garred et al. 1989, Michaelsen et al. 1991, Bruhns et al. 2009, Vidarsson et al. 2014, Rizvi et al. 2015a).

\section{Anti-PD-1 and anti-PD-L1 mAbs}

Hypophysitis with anti-PD-(L)1 mAbs is rarer than with anti-CTLA-4 antibodies. For example, in patients treated with nivolumab and pembrolizumab, only $0.6 \%$ developed hypophysitis, with a median time to onset of 4.2 months (range: 1.4-11 months) (Topalian et al. 2012, Robert et al. 2014, 2015b, Weber et al. 2015a, Ribas et al. 2016). For patients using durvalumab, a safety database that combined 1414 patients showed that only 1 patient $(<0.1 \%)$ developed hypophysitis, with accompanying hypopituitarism, adrenal insufficiency and diabetes insipidus (Rizvi et al. 2015a). Similarly, in 523 patients who received atezolizumab for treatment of urothelial carcinoma, hypophysitis was found in $0.2 \%(1 / 523$ urothelial carcinoma) (Rosenberg et al. 2016).

Hypophysitis was more frequently observed, similar to anti-CTLA-4 monotherapy (9\%), when combination therapy with anti-CTLA-4 and anti-PD-L1 was used (Wolchok et al. 2013, Larkin et al. 2015, Postow et al. 2015).

\section{Thyroid dysfunction}

Distinguishing between primary or secondary dysfunction of the thyroid gland is of paramount importance. Secondary (central) hypothyroidism, with low or normal TSH and low free $\mathrm{T}_{4}$, is due to central dysfunction and should lead to the suspicion of hypophysitis induced by anti-CTLA-4 mAbs. Primary hypothyroidism, with high TSH and normal or low free $\mathrm{T}_{4}$, is seen more with anti-PD-1 or anti-PD-L1 mAbs.

The incidence of thyroid dysfunction in patients treated with anti-PD-1 or anti-PD-L1 mAbs ranges from 4 to $19.5 \%$, with a variable time to onset (Table 2 ). In the study by Reck and coworkers that investigated pembrolizumab in patients with NSCLC, the incidence of hyperthyroidism and hypothyroidism was 7.8 and 9.1\%, respectively (Reck et al. 2016). In most studies, the majority of the cases are considered mild (grade 1 or 2) and resolution can be observed in $20-30 \%$ of patients with hypothyroidism and in up to $75 \%$ of patients with hyperthyroidism treated with nivolumab or pembrolizumab (Hamanishi et al. 2015, O'Donnell et al. 2015, Reck et al. 2016, El-Khoueiry et al. 2017).

The clinical manifestations of hypothyroidism include fatigue, weakness, asthenia, constipation, cold intolerance, dry skin and weight gain. Hyperthyroidism can be manifested as new-onset atrial fibrillation, diarrhea, heat intolerance, excessive diaphoresis and weight loss.

The spectrum of thyroid disturbances associated with immune checkpoint inhibitors include painless thyroiditis with transient thyrotoxicosis, transient or long-standing hypothyroidism, thyroid eye disease and occasionally severe forms of thyroid disease such as thyroid storm (Borodic et al. 2011, Hamnvik et al. 2011, Min et al. 2011, McElnea et al. 2014, Min \& Hodi 2014, Carl et al. 2015, Orlov et al. 2015, Yu et al. 2015, Joshi et al. 2016). Rare cases of Graves' ophtalmopathy have been reported with elevation of TSH-receptor antibodies but normal thyroid function (Borodic et al. 2011, Min et al. 2011).

The mechanism responsible for immunotherapyrelated thyroid dysfunction is still unclear. Orlov and coworkers reported 10 cases of painless thyroiditis syndrome following anti-PD1 therapy (Orlov et al. 2015). Six patients presented with an initial thyrotoxic phase from which $4(67 \%)$ were positive for anti-thyroid peroxidase (anti-TPO) and positive for antithyroglobulin (anti-Tg), whereas all were negative for thyrotropin binding inhibitory immunoglobulins (TBII). Thyrotoxicosis resolved spontaneously in all patients and was followed by hypothyroidism. There were 4 patients who presented with hypothyroidism without previously detected thyrotoxic phase and had serological evidence of positive anti-Tg and anti-TPO antibodies (Orlov et al. 2015).

\section{Anti-PD1 mAbs}

The incidence of thyroid dysfunction with nivolumab is similar to pembrolizumab (Lu et al. 2015, Reck et al. 2016)

Published by Bioscientifica Ltd. 
(Table 2). Hypothyroidism occurred in about $9 \%$ with a median time to onset of 2.9 months (1 day to 16.6 months). Resolution occurred in 35\% of patients. The incidence of hypothyroidism with pembrolizumab, evaluated in more than 2800 patients, was 7-9.1\%, mainly grade $2(6.2 \%)$ with a median time to onset of 3.5 months (1 day to 18.9 months) (Table 2). Hypothyroidism resolved in about $20 \%$ of the patients. The incidence of new or worsening hypothyroidism was higher in patients with head and neck squamous cell carcinoma (HNSCC) than with urothelial carcinoma, occurring in 28 (15\%) of 192 patients receiving pembrolizumab, including grade $3(0.5 \%)$ hypothyroidism. This higher frequency is likely related to external radiotherapy to the neck which by itself is a risk factor for hypothyroidism.

\section{Anti-PD-L1 mAbs}

In patients who received avelumab, hypothyroidism occurred in 90/1738 (5\%) patients and hyperthyroidism in 7 patients $(0.4 \%)$. The median time to onset of thyroid dysfunction was 2.8 months (2 weeks to 13 months). Thyroid disease resolved in 7 (7\%) of the 97 patients (Shitara et al. 2015, Yamada et al. 2015).

Across clinical trials for urothelial carcinoma and NSCLC with atezolizumab, hypothyroidism was found in $3.9 \%(77 / 1978)$ and hyperthyroidism in $1.0 \%(20 / 1978)$ (Rosenberg et al. 2016).

In the combined safety database using durvalumab, hypothyroidism occurred in 136/1414 (9.6\%), hyperthyroidism occurred in 9/182 (4.9\%), all were grade 1-2 and median time to first onset was 43 days (14-71 days). In another study, hyperthyroidism occurred in 81/1414 (5.7\%) (Rizvi et al. 2015a).

\section{Anti-CTLA4 mAbs}

The incidence of thyroid dysfunction in patients treated with ipilimumab ranges from 1 to 8.9\% (Ryder et al. 2014, Abdel-Rahman et al. 2016). The onset of anti-CTLA-4 thyroid dysfunction is variable, occurring after 2-4 infusions on average, but up to three years after the first infusion (Ryder et al. 2014). The male-to-female ratio of hypothyroidism was approximately 6:9. Most cases have a subclinical course or may be transient, but it can also evolve to permanent hypothyroidism with the need of thyroid hormone replacement. The administration of anti-CTLA-4 antibodies does not seem to worsen previous thyroid diseases. Hypophysitis and primary thyroid dysfunction may be concurrent, especially in patients in use of ipilimumab and anti-PD-1 agents.

Much higher incidence of hyper and hypothyroidism occurred when combination therapy with anti-CTLA-4 and anti-PD-L1 was used (16 and 14\%, respectively).

\section{Other endocrine irAEs}

\section{Primary adrenal insufficiency}

Primary adrenal insufficiency is rare. In patients using ipilimumab, $0.8-1.6 \%$ of the studied patients reported primary insufficiency after either monotherapy or combination with anti-PD-(L)1 therapy. With nivolumab, primary adrenal insufficiency occurred in 1\% (20/1994) of the patients and median time to onset was 4.3 months (range: 15 days to 21 months). In patients treated with avelumab, primary adrenal insufficiency occurred in $8 / 1738$ patients $(0.5 \%)$, and only one patient $(0.1 \%)$ had grade 3 adrenal insufficiency. The median time to onset of primary adrenal insufficiency for avelumab is 2.5 months (range: 1 day to 8 months). With atezolizumab, primary adrenal insufficiency occurred in 0.4\% (7/1978), two with grade 3 and 5 with grade $1-2$. In the combined safety database using durvalumab, the frequency of primary adrenal insufficiency was $0.9 \%(13 / 1414)$, being grade 3 in $0.1 \%$ (Table 2 ).

Despite the lack of clinically manifest hypoadrenalism, there have been recent reports of radiological evidence of adrenalitis, newly symmetrically and smoothly enlarged adrenal glands, with normal endocrine function following immune checkpoint therapy, consistent with a subclinical form of adrenalitis (Bacanovic et al. 2015).

\section{Type 1 diabetes mellitus}

Type 1 diabetes mellitus (DM) is not a frequent adverse event observed in patients treated with immunotherapy. It has not been reported with the use of ipilimumab alone so far. Type 1 DM occurred in $0.9 \%$ of patients treated with nivolumab and in $0.2 \%$ of patients treated with pembrolizumab. Diabetic ketoacidosis was reported in a few of these cases. The median time to onset was 4.4 months (range: 15 days to 22 months) (Robert et al. $2015 a, b$, Ribas et al. 2016). In patients who received avelumab, type 1 diabetes occurred in $0.1 \%(2 / 1738)$, all presented with grade 3 hyperglycemia. For atezolizumab, one patient with urothelial carcinoma and three patients with NSCLC of 1978 patients developed type 1 DM (Spira et al. 2015, Yamada et al. 2015). In the combined safety

Published by Bioscientifica Ltd. 
database of durvalumab, type 1 DM occurred in only one (0.1\%) patient (Hamid et al. 2013, Rizvi et al. 2015b, Shitara et al. 2015, Spira et al. 2015, Yamada et al. 2015).

\section{Hypoparathyroidism}

Recently, there was a report of a case of symptomatic hypocalcemia due to acute hypoparathyroidism in a patient using combination of nivolumab and ipilimumab (Win et al. 2017).

\section{Diagnosis and treatment}

\section{Pituitary dysfunctions}

Monitoring In addition to baseline pituitary function tests, regular monitoring of $\mathrm{TSH}$ and free $\mathrm{T}_{4}$ is recommended monthly during treatment and should also be promptly ordered when suggesting symptoms of hypophysitis are present. When using anti-CTLA-4 agents, ACTH and cortisol levels should also be assessed routinely (Fig. 1).

Diagnosis In the suspicion of hypophysitis, a MRI should be performed to evaluate the pituitary and to exclude other causes of pituitary dysfunction such as brain metastases. A hormone profile assessment should be carried out, including TSH and free $\mathrm{T}_{4}$, ACTH, cortisol, $\mathrm{LH}, \mathrm{FSH}$, prolactin, estradiol in females and testosterone in males. As diabetes insipidus is extremely rare, it should be investigated only in the presence of symptoms such as polyuria and polydipsia (Dillard et al. 2010). It is important to note that many metastatic patients receive corticosteroids, which impair evaluation of the pituitaryadrenal axis.

The diagnosis of hypophysitis is presumptive and is based on the presence of laboratory abnormalities suggestive of hypopituitarism and reversible pituitary enlargement seen at MRI, although since pituitary enlargement is transient and often mild, pituitary MRI may be normal especially if imaging is delayed. Severe fatigue, headache and myalgia should lead to the suspicion of hypophysitis and pituitary MRI should be promptly requested. Secondary adrenal insufficiency is confirmed by the presence of normal or low morning adrenocorticotropic hormone (ACTH) and low or undetectable cortisol levels. The ACTH (cosyntropin) stimulation test can be performed; however, it is important to note that sensitivity can be lower with early secondary adrenal insufficiency as adrenal glands might maintain response to ACTH in the acute phase of pituitary damage (Mitchell et al. 2009). In these cases, the low-dose ACTH stimulation test $(1 \mu \mathrm{g})$ could be an option (Kazlauskaite et al. 2008, Ospina et al. 2016).

Secondary hypothyroidism is diagnosed by the presence of normal or low thyroid-stimulating hormone (TSH) with low free thyroxine $\left(\mathrm{FT}_{4}\right)$ levels. To a lesser extent, secondary hypogonadism may also occur and the growth hormone axis is usually spared. Serum prolactin can be low, normal or high; the latter likely secondary to compression of the stalk.

Routine monitoring is critical as patients may be oligosymptomatic and symptoms may be vague, such as fatigue. Additionally, the use of exogenous glucocorticoids may mask the diagnosis of hypophysitis, so that a clinician must have a high index of suspicion, especially when glucocorticoids are tapered or weaned off to avoid adrenal crisis. Another possible confounding factor occurs with cancer patients undergoing chemotherapy, who can present with low TSH and central hypogonadism. These alterations may complicate initial assessment of thyrotroph and gonadotroph function following ipilimumab therapy. Figure 1 summarizes a suggested recommendation for biochemical evaluation and monitoring of pituitary dysfunction in patients treated with immunotherapy.

Treatment Glucocorticoid and thyroid hormone replacement should be introduced following a diagnosis of hypophysitis; steroid replacement should precede levothyroxine to avoid adrenal crisis. Testosterone replacement in men and estradiol replacement in selected premenopausal women should be considered. Growth hormone treatment is contraindicated. While some patients recover hormonal function, the use of concomitant treatments, such as glucocorticoid therapy and external beam radiotherapy, may impact recovery (Downey et al. 2007, Faje et al. 2014, Ryder et al. 2014). In fact, recovery of the adrenal axis is rare. In the subset of patients with improvement of the pituitary function what is observed is the recovery of the thyroidal and gonadal axis. The time to recovery has not been defined and hypopituitarism may persist in some patients indefinitely (Faje 2016).

Usually, immunotherapy can be maintained since pituitary hormones can safely be replaced. Cancer treatment should only be withheld, temporarily, in the rare occasions when there are symptoms related to mass effect of pituitary enlargement, such as vision loss and headache.

Published by Bioscientifica Ltd. 
PRIMARY THYROID DYSFUNCTION

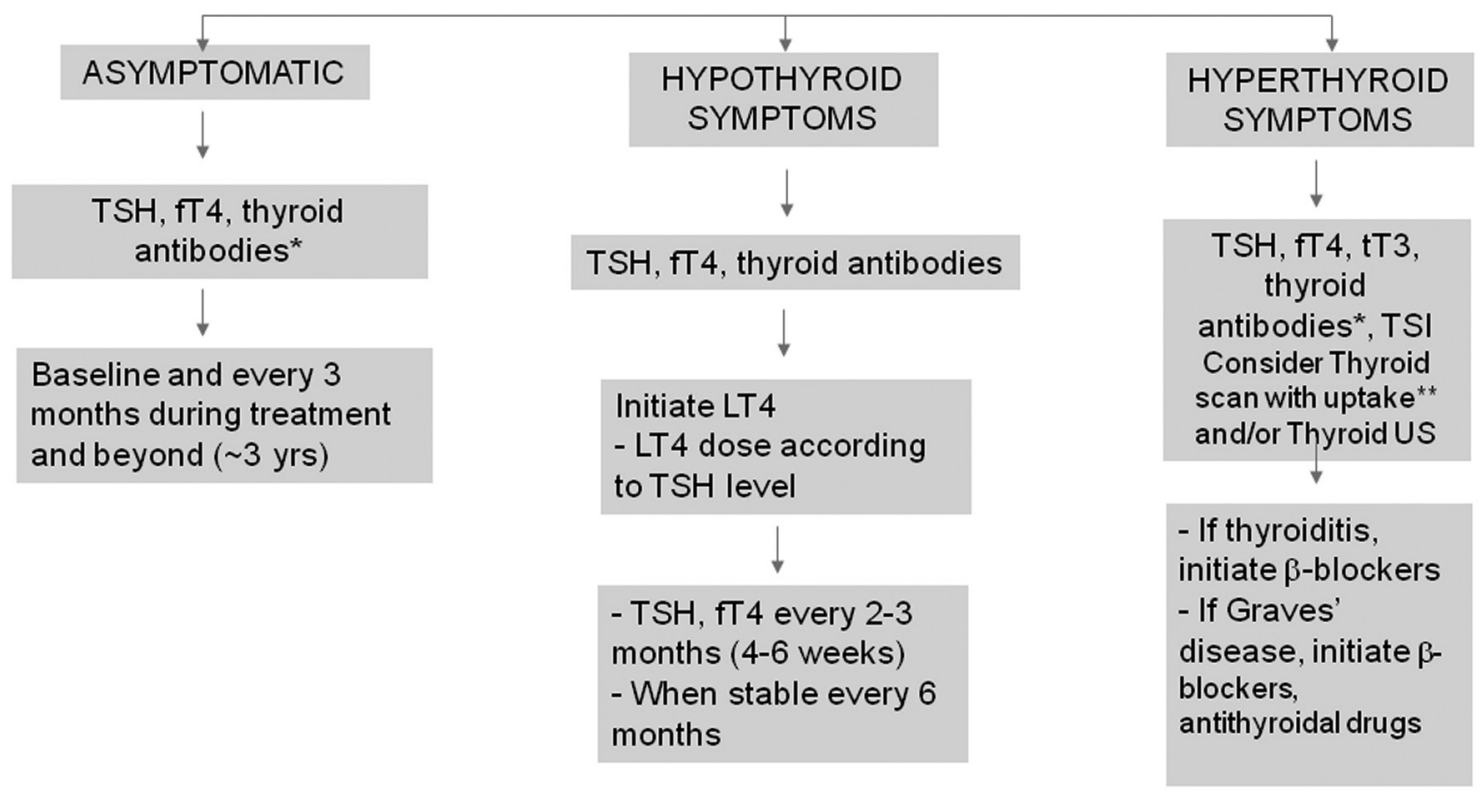

\section{Figure 2}

Suggested recommendation for biochemical evaluation and monitoring of thyroid dysfunction in patients treated with immunotherapy. ${ }^{*}$ Thyroid antibodies: thyroid peroxidase and thyroglobulin antibodies. ${ }^{*}$ Radioactive iodine and technetium uptake is inaccurate in face of recent use of iodine

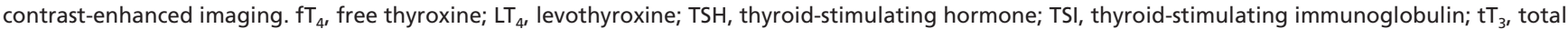
triiodothyronine; US, ultrasound.

High-dose steroids (prednisolone $0.5-1 \mathrm{mg} / \mathrm{kg} / \mathrm{day}$ or equivalent) is appropriate for patients with severe symptoms from hypopituitarism or from hypophysitis, including patients with severe hyponatremia from adrenal insufficiency and patients with headache and visual abnormalities from pituitary enlargement abutting the optic chiasm. Otherwise, patients with mild symptoms of hypophysitis and hypopituitarism can be treated with lower doses or physiologic doses of steroids (for example, 20-30 mg of hydrocortisone in split doses or an equivalent dose of prednisone) (Faje et al. 2014, Min et al. 2015).

In a subset of patients, pituitary function recovery may occur, mainly thyroidal and gonadal axis recovery. Adrenal axis recovery is rare. The time of function recovery is not well defined, and hypopituitarism may persist in some patients indefinitely (Faje 2016).

\section{Thyroid dysfunction}

Monitoring In addition to baseline thyroid function tests (TFT), regular monitoring of thyroid hormone levels (TSH and free $\mathrm{T}_{4}$ ) is recommended before each treatment and also should be promptly accessed when suggesting symptoms are present (Fig. 2).
Diagnosis Persistently abnormal (particularly low) TSH levels, with low free $\mathrm{T}_{4}$ may represent secondary hypothyroidism resulting from immunotherapy-induced hypophysitis. However, suppressed TSH levels may also occur due to high-dose steroids administered for other irAEs or brain metastases. Thus, in the appropriate clinical context, low TSH levels with normal or low $\mathrm{FT}_{4}$ levels should prompt evaluation, if not already performed, of the pituitary-adrenal axis with a morning ACTH and cortisol level.

In thyroiditis, primary hypothyroidism (high TSH and/or low free $\mathrm{T}_{4}$ ) might be preceded by a transient hyperthyroidism (low TSH, elevated free $\mathrm{T}_{4}$ and/or $\mathrm{T}_{3}$ ). Thyroid antibodies, antithyroglobulin and anti-thyroid peroxidase (TPO), should be measured when a primary thyroid dysfunction is suspected.

Treatment Asymptomatic patients with mildly elevated TSH $(<10 \mathrm{U} / \mathrm{L})$ usually can be only observed. If required, thyroid hormone therapy should be initiated as an initial full replacement or as partial replacement with gradual increments in the dose titrated upward using serum TSH as the goal. Dose adjustments should be made with TSH assessment 4-6 weeks after any dosage

Published by Bioscientifica Ltd 
change. In the absence of other immunotherapy-induced endocrine dysfunction, patients do not require treatment with glucocorticoid.

Thyroiditis with transient thyrotoxicosis can be managed symptomatically with $\beta$-blockers. Anti-thyroid drugs are rarely needed and are indicated to patients with thyroid hormone overproduction such as in Graves' disease. To distinguish between thyroiditis and Graves' disease, a thyroid scan with uptake could be performed. However, the use of iodine contrast-enhanced imaging in oncological patients frequently precludes its use. An alternative, when expertise is available, is ultrasonography with color flow Doppler where increased flow suggests thyroid hyperactivity while hypovascularity suggests destructive thyroiditis. Immunoassays to detect thyroidstimulating immunoglobulin, TPO and thyroglobulin antibodies can be helpful in this setting. Those patients with mild symptoms of hyperthyroidism from thyroiditis can be observed and monitored for symptom progression, as well as for the development of permanent hypothyroidism.

Immunotherapy can be maintained, unless in case of severe thyrotoxicosis when the drug might be paused until symptoms improve.

\section{Primary adrenal insufficiency}

Diagnosis Primary adrenal insufficiency associated with adrenal crisis is exceedingly rare (Hodi et al. 2010, Brahmer et al. 2012, Corsello et al. 2013, Hamid et al. 2013). It may be diagnosed by the presence of volume depletion, electrolyte disturbances, eosinophilia and low or suppressed morning serum cortisol with high ACTH levels. Immunotherapy usually can be maintained.

Adrenal crisis is the most life-threatening endocrinopathy requiring prompt diagnosis and treatment. Adrenal crisis usually presents as hypovolemic shock, associated with nonspecific symptoms such as nausea, vomiting, fatigue, lethargy, confusion or coma. If suspected, serum cortisol and ACTH should be obtained and treatment should be initiated immediately thereafter, without waiting for results. Treatment consists of intravenous hydrocortisone, $100 \mathrm{mg}$ every $6-8 \mathrm{~h}$ in addition to aggressive fluid replacement. Endocrinology consultation is highly recommended.

\section{Autoimmune diabetes}

Type 1 DM may rarely occur and when present, ketoacidosis must be investigated and treated, mainly if serum glucose is greater than $250 \mathrm{mg} / \mathrm{dL}$ (Kitabchi et al. 2009). Appropriate treatment with basal-bolus insulin is recommended. Anti-GAD65 can be performed to confirm the autoimmunity.

\section{Conclusion}

Given the breadth of the emerging immunotherapy field, clinicians should be aware of the unique set of drug-related adverse effects, now known as immune-related adverse events (irAE). Predicting and understanding the aforementioned toxicity will require better reporting of these toxicities, as well as more translational research.

With regards to endocrine disorders, hypophysitis and thyroid dysfunction are the most common abnormalities. For patients on anti-CTLA-4 treatment, the pituitary hormone profile should be appropriately monitored throughout immunotherapy and treatment should be instituted as soon as central adrenal insufficiency and/or central hypothyroidism is diagnosed.

Primary thyroid dysfunction is more frequently observed in patients treated with anti-PD1 and antiPD-L1 antibodies. Both primary hypothyroidism and hyperthyroidism can occur. Hyperthyroidism can be transient, but followed by hypothyroidism, which may require lifelong treatment.

Endocrine side effects should be promptly diagnosed and treated as they result in reduced quality of life and reduced tolerance to immunotherapy. As in most cases, endocrine side effects can be adequately managed, and they do not contraindicate the continued use of immunotherapy.

Physicians should be aware that autoimmune endocrine disorders can occur during and long after immunotherapy and a multidisciplinary approach is strongly recommended. In addition, patient education regarding irAEs is of utmost importance so that notification of symptoms prompts early diagnosis and treatment.

\section{Declaration of interest}

The authors declare that there is no conflict of interest that could be perceived as prejudicing the impartiality of this review.

\section{Funding}

This research did not receive any specific grant from any funding agency in the public, commercial or not-for-profit sector.
(C) 2018 Society for Endocrinology Printed in Great Britain
Published by Bioscientifica Ltd 


\section{References}

Abdel-Rahman O, ElHalawani H \& Fouad M 2016 Risk of endocrine complications in cancer patients treated with immune check point inhibitors: a meta-analysis. Future Oncology 12 413-425. (doi:10.2217/fon.15.222)

Aglietta M, Barone C, Sawyer MB, Moore MJ, Miller WH Jr, Bagalà C, Colombi F, Cagnazzo C, Gioeni L, Wang E, et al. 2014 A phase I dose escalation trial of tremelimumab $(\mathrm{CP}-675,206)$ in combination with gemcitabine in chemotherapy-naive patients with metastatic pancreatic cancer. Annals of Oncology 25 1750-1755. (doi:10.1093/ annonc/mdu205)

Albarel F, Gaudy C, Castinetti F, Carré T, Morange I, Conte-Devolx B, Grob JJ \& Brue T 2015 Long-term follow-up of ipilimumab-induced hypophysitis, a common adverse event of the anti-CTLA-4 antibody in melanoma. European Journal of Endocrinology 172 195-204. (doi:10.1530/EJE-14-0845)

Altomonte M, Di Giacomo A, Queirolo P, Ascierto P, Spagnolo F, Bajetta E, Calabrò L, Danielli R, de Rosa F, Maur M, et al. 2013 Clinical experience with ipilimumab $10 \mathrm{mg} / \mathrm{kg}$ in patients with melanoma treated at Italian centres as part of a European expanded access programme. Journal of Experimental and Clinical Cancer Research 32 82. (doi:10.1186/1756-9966-32-82)

Ansell SM, Hurvitz SA, Koenig PA, LaPlant BR, Kabat BF, Fernando D, Habermann TM, Inwards DJ, Verma M, Yamada R, et al. 2009 Phase I study of ipilimumab, an anti-CTLA-4 monoclonal antibody, in patients with relapsed and refractory B-cell non-Hodgkin lymphoma. Clinical Cancer Research 15 6446-6453. (doi:10.1158/1078-0432.CCR09-1339)

Ansell SM, Lesokhin AM, Borrello I, Halwani A, Scott EC, Gutierrez M, Schuster SJ, Millenson MM, Cattry D, Freeman GJ, et al. 2015 PD-1 blockade with nivolumab in relapsed or refractory Hodgkin's lymphoma. New England Journal of Medicine 372 311-319. (doi:10.1056/NEJMoa1411087)

Antonia SJ, Bendell JC, Taylor MH, Calvo E, Jaeger D, Braud FGD, Ott PA, Pietanza MC, Horn L, Le DT, et al. 2015a Phase I/II study of nivolumab with or without ipilimumab for treatment of recurrent small cell lung cancer (SCLC): CA209-032. Journal of Clinical Oncology 33 (15 Suppl) 7503. (doi:10.1200/jco.2015.33.15_suppl.7503)

Antonia SJ, Goldberg SB, Balmanoukian AS, Sanborn RE, Steele K, Narwal R, Robbins PB, Gu Y, Karakunnel JJ \& Rizvi NA 2015b Phase Ib study of MEDI4736, a programmed cell death ligand-1 (PD-L1) antibody, in combination with tremelimumab, a cytotoxic T-lymphocyte-associated protein-4 (CTLA-4) antibody, in patients (pts) with advanced NSCLC. Journal of Clinical Oncology 33 (15 Suppl) 3014 (doi:10.1200/jco.2015.33.15_suppl.3014)

Antonia SJ, López-Martin JA, Bendell J, Ott PA, Taylor M, Eder JP, Jäger D, Pietanza MC, Le DT, de Braud F, et al. 2016 Nivolumab alone and nivolumab plus ipilimumab in recurrent small-cell lung cancer (CheckMate 032): a multicentre, open-label, phase $1 / 2$ trial. Lancet Oncology 17 883-895. (doi:10.1016/S1470-2045(16)30098-5)

Atkins MB, Choueiri TK, Hodi FS, Thompson JA, Hwu WJ, McDermott DF, Brookes M, Tosolini A, Ebbinghaus S, Yang Z, et al. 2015 Pembrolizumab (MK-3475) plus low-dose ipilimumab (IPI) in patients (pts) with advanced melanoma (MEL) or renal cell carcinoma (RCC): data from the KEYNOTE-029 phase 1 study. Journal of Clinical Oncology 33 (15 Suppl) 3009 (doi:10.1200/ jco.2015.33.15_suppl.3009)

Attia P, Phan GQ, Maker AV, Robinson MR, Quezado MM, Yang JC, Sherry RM, Topalian SL, Kammula US, Royal RE, et al. 2005 Autoimmunity correlates with tumor regression in patients with metastatic melanoma treated with anti-cytotoxic T-lymphocyte antigen-4. Journal of Clinical Oncology 23 6043-6053. (doi:10.1200/ JCO.2005.06.205)

Bacanovic S, Burger IA, Stolzmann P, Hafner J \& Huellner MW. 2015 Ipilimumab-induced adrenalitis: a possible pitfall in 18F-FDG-PET/
CT. Clinical Nuclear Medicine 40 518-519. (doi:10.1097/ RLU.0000000000000887)

Bauer TM, McCleod M, Chandler JC, Blumenschein GR, Schwartzberg LS, Burris H, Waterhouse D, Jotte RM, Hussein M, Spigel DR, et al. 2015 An ongoing phase IIIb/IV safety trial of nivolumab (NIVO) in patients (pts) with advanced or metastatic non-small-cell lung cancer (NSCLC) w.ho progressed after receiving 1 or more prior systemic regimens. Journal of Clinical Oncology 33 (15 Suppl) 3013 (doi:10.1200/jco.2015.33.15_suppl.3013)

Borghaei H, Paz-Ares L, Horn L, Spigel DR, Steins M, Ready NE, Chow LQ, Vokes EE, Felip E, Holgado E, et al. 2015 Nivolumab versus docetaxel in advanced nonsquamous non-small-cell lung cancer. New England Journal of Medicine 373 1627-1639. (doi:10.1056/NEJMoa1507643)

Borodic G, Hinkle DM \& Cia Y 2011 Drug-induced graves disease from CTLA-4 receptor suppression. Ophthalmic Plastic and Reconstructive Surgery 27 e87-e88. (doi:10.1097/IOP.0b013e3181ef72a1)

Bossart S, Thurneysen S, Rushing E, Frontzek K, Leske H, MihicProbst D, Nagel HW, Mangana J, Goldinger SM \& Dummer R 2017 Case report: encephalitis, with brainstem involvement, following checkpoint inhibitor therapy in metastatic melanoma. Oncologist 22 749-753. (doi:10.1634/theoncologist.2016-0366)

Boussiotis VA 2016 Molecular and biochemical aspects of the PD-1 checkpoint pathway. New England Journal of Medicine $\mathbf{3 7 5}$ 1767-1778. (doi:10.1056/NEJMra1514296)

Boutros C, Tarhini A, Routier E, Lambotte O, Ladurie FL, Carbonnel F, Izzeddine H, Marabelle A, Champiat S, Berdelou A, et al. 2016 Safety profiles of anti-CTLA-4 and anti-PD-1 antibodies alone and in combination. Nature Reviews Clinical Oncology 13 473-486. (doi:10.1038/nrclinonc.2016.58)

Brahmer JR, Drake CG, Wollner I, Powderly JD, Picus J, Sharfman WH, Stankevich E, Pons A, Salay TM, McMiller TL, et al. 2010 Phase I study of single-agent anti-programmed death-1 (MDX-1106) in refractory solid tumors: safety, clinical activity, pharmacodynamics, and immunologic correlates. Journal of Clinical Oncology $\mathbf{2 8}$ 3167-3175. (doi:10.1200/JCO.2009.26.7609)

Brahmer JR, Tykodi SS, Chow LQ, Hwu WJ, Topalian SL, Hwu P, Drake CG, Camacho LH, Kauh J, Odunsi K, et al. 2012 Safety and activity of anti-PD-L1 antibody in patients with advanced cancer. New England Journal of Medicine 366 2455-2465. (doi:10.1056/ NEJMoa1200694)

Brahmer J, Reckamp KL, Baas P, Crinò L, Eberhardt WE, Poddubskaya E, Antonia S, Pluzanski A, Vokes EE, Holgado E, et al. 2015 Nivolumab versus docetaxel in advanced squamous-cell non-small-cell lung cancer. New England Journal of Medicine 373 123-135. (doi:10.1056/ NEJMoa1504627)

Bruhns P, Iannascoli B, England P, Mancardi DA, Fernandez N, Jorieux S \& Daëron M 2009 Specificity and affinity of human Fcgamma receptors and their polymorphic variants for human IgG subclasses. Blood 113 3716-3725. (doi:10.1182/blood-2008-09-179754)

Byun DJ, Wolchok JD, Rosenberg LM \& Girotra M 2017 Cancer immunotherapy - immune checkpoint blockade and associated endocrinopathies. Nature Reviews Endocrinology 13 195-207. (doi:10.1038/nrendo.2016.205)

Calabrò L, Morra A, Fonsatti E, Cutaia O, Fazio C, Annesi D, Lenoci M, Amato G, Danielli R, Altomonte M, et al. 2015 Efficacy and safety of an intensified schedule of tremelimumab for chemotherapy-resistant malignant mesothelioma: an open-label, single-arm, phase 2 study. Lancet Respiratory Medicine 3 301-309. (doi:10.1016/S22132600(15)00092-2)

Camacho LH, Antonia S, Sosman J, Kirkwood JM, Gajewski TF, Redman B, Pavlov D, Bulanhagui C, Bozon VA, Gomez-Navarro J, et al. 2009 Phase I/II trial of tremelimumab in patients with metastaticmelanoma. Journal of Clinical Oncology 27 1075-1081. (doi:10.1200/JCO.2008.19.2435)
○ 2018 Society for Endocrinology Printed in Great Britain 
Carl D, Grüllich C, Hering S \& Schabet M 2015 Steroid responsive encephalopathy associated with autoimmune thyroiditis following ipilimumab therapy: a case report. BMC Research Notes 8316. (doi:10.1186/s13104-015-1283-9)

Chen DS, Irving BA \& Hodi FS 2012 Molecular pathways: next generation immunotherapy: inhibiting programmed death-ligand 1 and programmed death-1. Clinical Cancer Research 18 6580-6587. (doi:10.1158/1078-0432.CCR-12-1362)

Chiarion-Sileni V, Pigozzo J, Ascierto PA, Simeone E, Maio M, Calabrò L, Marchetti P, De Galitiis F, Testori A, Ferrucci PF, et al. 2014 Ipilimumab retreatment in patients with pretreated advanced melanoma: the expanded access programme in Italy. British Journal of Cancer 110 1721-1726. (doi:10.1038/bjc.2014.126)

Cho DC, Sosman JA, Sznol M, Gordon MS, Hollebecque A, Hamid O, McDermott DF, Delord JP, Rhee IP, Mokatrin A, et al. 2013 Clinical activity, safety, and biomarkers of MPDL3280A, an engineered PD-L1 antibody in patients with metastatic renal cell carcinoma (mRCC). Journal of Clinical Oncology 31 (15 Suppl) 4505 (doi:10.1200/ jco.2013.31.15_suppl.4505)

Chung KY, Gore I, Fong L, Venook A, Beck SB, Dorazio P, Criscitiello PJ, Healey DI, Huang B, Gomez-Navarro J, et al. 2010 Phase II study of the anti-cytotoxic T-lymphocyte-associated antigen 4 monoclonal antibody, tremelimumab, in patients with refractory metastatic colorectal cancer. Journal of Clinical Oncology 28 3485-3490. (doi:10.1200/JCO.2010.28.3994)

Corsello SM, Barnabei A, Marchetti P, De Vecchis L, Salvatori R \& Torino F 2013 Endocrine side effects induced by immune checkpoint inhibitors. Journal of Clinical Endocrinology and Metabolism 98 1361-1375. (doi:10.1210/jc.2012-4075)

Crews J, Agarwal A, Jack L, Xu D, Do DV \& Nguyen QD 2015 Ipilimumab-associated retinopathy. Ophthalmic Surgery, Lasers and Imaging Retina 46 658-660. (doi:10.3928/23258160-20150610-10)

Di Giacomo AM, Danielli R, Calabrò L, Bertocci E, Nannicini C, Giannarelli D, Balestrazzi A, Vigni F, Riversi V, Miracco C, et al. 2011 Ipilimumab experience in heavily pretreated patients with melanoma in an expanded access program at the University Hospital of Siena (Italy). Cancer Immunology, Immunotherapy 60 467-477. (doi:10.1007/s00262-010-0958-2)

Di Giacomo AM, Ascierto PA, Pilla L, Santinami M, Ferrucci PF, Giannarelli D, Marasco A, Rivoltini L, Simeone E, Nicoletti SV, et al. 2012 Ipilimumab and fotemustine in patients with advanced melanoma (NIBIT-M1): an open-label, single-arm phase 2 trial. Lancet Oncology 13 879-886. (doi:10.1016/S1470-2045(12)70324-8)

Disis ML, Patel MR, Pant S, Infante JR, Lockhart AC, Kelly K, Beck JT, Gordon MS Weiss GJ, Ejadi S, et al. 2015 Avelumab (MSB0010718C), an anti-PD-L1 antibody, in patients with previously treated, recurrent or refractory ovarian cancer: a phase Ib, open-label expansion trial. Journal of Clinical Oncology 33 (15 Suppl) 5509 (doi:10.1200/jco.2015.33.15_suppl.5509)

Dillard T, Yedinak CG, Alumkal J \& Fleseriu M 2010 Anti-CTLA-4 antibody therapy associated autoimmune hypophysitis: serious immune related adverse events across a spectrum of cancer subtypes. Pituitary 13 29-38. (doi:10.1007/s11102-009-0193-z)

Doi T, Piha-Paul SA, Jalal SI, Mai-Dang H, Yuan S, Koshiji M, Csiki I \& Bennouna J 2015 Pembrolizumab (MK-3475) for patients (pts) with advanced esophageal carcinoma: Preliminary results from KEYNOTE-028. Journal of Clinical Oncology 33 (3 Suppl) 4010 (doi:10.1200/jco.2015.33.3_suppl.774)

Downey SG, Klapper JA, Smith FO, Yang JC, Sherry RM, Royal RE, Kammula US, Hughes MS, Allen TE, Levy CL, et al. 2007 Prognostic factors related to clinical response in patients with metastatic melanoma treated by CTL-associated antigen- 4 blockade. Clinical Cancer Research 13 6681-6688. (doi:10.1158/1078-0432.CCR-070187)

Eggermont AM, Chiarion-Sileni V, Grob JJ, Dummer R, Wolchok JD, Schmidt H, Hamid O, Robert C, Ascierto PA, Richards JM, et al. 2016
Prolonged survival in stage III melanoma with ipilimumab adjuvant therapy. New England Journal of Medicine 375 1845-1855. (doi:10.1056/NEJMoa1611299)

El-Khoueiry AB, Melero I, Crocenzi TS, Welling TH, Yau TC, Yeo W, Chopra A, Grosso J, Lang L, Anderson J, et al. 2015 Phase I/II safety and antitumor activity of nivolumab in patients with advanced hepatocellular carcinoma (HCC): CA209-040. Journal of Clinical Oncology 33 (18 Suppl) LBA101 (doi:10.1200/jco.2015.33.18_suppl. lba101)

El-Khoueiry AB, Sangro B, Yau T, Crocenzi TS, Kudo M, Hsu C, Kim TY, Choo SP, Trojan J, Welling TH, et al. 2017 Nivolumab in patients with advanced hepatocellular carcinoma (CheckMate 040): an openlabel, non-comparative, phase $1 / 2$ dose escalation and expansion trial. Lancet 389 2492-2502. (doi:10.1016/S0140-6736(17)31046-2)

Faje A 2016 Immunotherapy and hypophysitis: clinical presentation, treatment, and biologic insights. Pituitary 19 82-92. (doi:10.1007/ s11102-015-0671-4)

Faje AT, Sullivan R, Lawrence D, Tritos NA, Fadden R, Klibanski A \& Nachtigall L 2014 Ipilimumab-induced hypophysitis: a detailed longitudinal analysis in a large cohort of patients with metastatic melanoma. Journal of Clinical Endocrinology and Metabolism 99 4078-4085. (doi:10.1210/jc.2014-2306)

Ferris RL, Blumenschein G, Fayette J, Guigay J, Colevas AD, Licitra L, Harrington K, Kasper S, Vokes EE, Even C, et al. 2016 Nivolumab for recurrent squamous-cell carcinoma of the head and neck. New England Journal of Medicine 375 1856-1867. (doi:10.1056/ NEJMoa1602252)

Francisco LM, Sage PT \& Sharpe AH 2010 The PD-1 pathway in tolerance and autoimmunity. Immunological Reviews 236 219-242. (doi:10.1111/j.1600-065X.2010.00923.x)

Friedman CF, Proverbs-Singh TA \& Postow MA 2016 Treatment of the immune-related adverse effects of immune checkpoint inhibitors: a review. JAMA Oncology 2 1346-1353. (doi:10.1001/ jamaoncol.2016.1051)

Garon EB, Rizvi NA, Hui R, Leighl N, Balmanoukian AS, Eder JP, Patnaik A, Aggarwal C, Gubens M, Horn L, et al. 2015 Pembrolizumab for the treatment of non-small-cell lung cancer. New England Journal of Medicine 372 2018-2028. (doi:10.1056/ NEJMoa1501824)

Garred P, Michaelsen TE \& Aase A 1989 The IgG subclass pattern of complement activation depends on epitope density and antibody and complement concentration. Scandinavian Journal of Immunology 30 379-382. (doi:10.1111/j.1365-3083.1989.tb01225.x)

Gettinger SN, Hellmann MD, Shepherd FA, Antonia SJ, Brahmer JR, Chow LQM, Goldman JW, Juergens RA, Borghaei H, Ready N, et al. 2015 First-line monotherapy with nivolumab (NIVO; antiprogrammed death-1 [PD-1]) in advanced non-small cell lung cancer (NSCLC): safety, efficacy and correlation of outcomes with PD-1 ligand (PD-L1) expression. Journal of Clinical Oncology 33 (15 Suppl) 8025. (doi:10.1200/jco.2015.33.15_suppl.8025)

González-Rodríguez E, Rodríguez-Abreu D \& Spanish Group for Cancer Immuno-Biotherapy (GETICA) 2016 Immune checkpoint inhibitors: review and management of endocrine adverse events. Oncologist 21 804-816. (doi:10.1634/theoncologist.2015-0509)

Gulley JL, Spigel D, Kelly K, Chandler JC, Rajan A, Hassan R, Wong DJL, Leach J, Edenfield WJ, Wang D, et al. 2015 Avelumab (MSB0010718C), an anti-PD-L1 antibody, in advanced NSCLC patients: a phase $1 \mathrm{~b}$, open-label expansion trial in patients progressing after platinum-based chemotherapy. Journal of Clinical Oncology 33 (15 Suppl) 8034. (doi:10.1200/jco.2015.33.15_ suppl.8034)

Hamanishi J, Mandai M, Ikeda T, Minami M, Kawaguchi A, Murayama T, Kanai M, Mori Y, Matsumoto S, Chikuma S, et al. 2015 Safety and antitumor activity of anti-PD-1 antibody, nivolumab, in patients with platinum-resistant ovarian cancer. Journal of Clinical Oncology 33 4015-4022. (doi:10.1200/JCO.2015.62.3397) 
Hamid O, Robert C, Daud A, Hodi FS, Hwu WJ, Kefford R, Wolchok JD, Hersey P, Joseph RW, Weber JS, et al. 2013 Safety and tumor responses with lambrolizumab (anti-PD-1) in melanoma. New England Journal of Medicine 369 134-144. (doi:10.1056/ NEJMoa1305133)

Hammers HJ, Plimack ER, Sternberg C, McDermott DF, Larkin JMG, Ravaud A, Rini BI, Sharma P, Bhagavatheeswaran P, Gagnier P, et al. 2015 CheckMate 214: a phase III, randomized, open-label study of nivolumab combined with ipilimumab versus sunitinib monotherapy in patients with previously untreated metastatic renal cell carcinoma. Journal of Clinical Oncology 33 (15 Suppl) TPS4578 (doi:10.1200/jco.2015.33.15_suppl.tps4578)

Hamnvik OP, Larsen PR \& Marqusee E 2011 Thyroid dysfunction from antineoplastic agents. Journal of the National Cancer Institute $\mathbf{1 0 3}$ 1572-1587. (doi:10.1093/jnci/djr373)

Hellmann MD, Rizvi NA, Goldman JW, Gettinger SN, Borghaei H, Brahmer JR, Ready NE, Gerber DE, Chow LQ, Juergens RA, et al. 2017 Nivolumab plus ipilimumab as first-line treatment for advanced non-small-cell lung cancer (CheckMate 012): results of an open-label, phase 1, multicohort study. Lancet Oncology 18 31-41. (doi:10.1016/S1470-2045(16)30624-6)

Henderson AD \& Thomas DA 2015 A case report of orbital inflammatory syndrome secondary to ipilimumab. Ophthalmic Plastic and Reconstructive Surgery 31 68-70. (doi:10.1097/IOP.0000000000000081)

Herbst RS, Gordon MS, Fine GD, Sosman JA, Soria JC, Hamid O, Powderly JD, Burris HA, Mokatrin A, Kowanetz M, et al. 2013 A study of MPDL3280A, an engineered PD-L1 antibody in patients with locally advanced or metastatic tumors. Journal of Clinical Oncology 31 (15 Suppl) 3000. (doi:10.1200/jco.2013.31.15_ suppl.3000)

Hersh EM, O’Day SJ, Powderly J, Khan KD, Pavlick AC, Cranmer LD, Samlowski WE, Nichol GM, Yellin MJ \& Weber JS 2011 A phase II multicenter study of ipilimumab with or without dacarbazine in chemotherapy-naïve patients with advancedmelanoma. Investigational New Drugs 29 489-498. (doi:10.1007/s10637-0099376-8)

Hodi FS, O'Day SJ, McDermott DF, Weber RW, Sosman JA, Haanen JB, Gonzalez R, Robert C, Schadendorf D, Hassel JC, et al. 2010 Improved survival with ipilimumab in patients with metastatic melanoma. New England Journal of Medicine 363 711-723. (doi:10.1056/NEJMoa1003466)

Hodi FS, Lee S, McDermott DF, Rao UN, Butterfield LH, Tarhini AA, Leming P, Puzanov I, Shin D \& Kirkwood JM 2014 Ipilimumab plus sargramostim vs ipilimumab alone for treatment of metastatic melanoma: a randomized clinical trial. JAMA 312 1744-1753. (doi:10.1001/jama.2014.13943)

Hodi FS, Postow MA, Chesney JA, Pavlick AC, Robert C, Grossmann KF, McDermott DF, Linette GP, Meyer N, Giguere JK, et al. 2015 Clinical response, progression-free survival (PFS), and safety in patients (pts) with advanced melanoma (MEL) receiving nivolumab (NIVO) combined with ipilimumab (IPI) vs IPI monotherapy in CheckMate 069 study. Journal of Clinical Oncology 33 (15 Suppl) 9004. (doi:10.1200/jco.2015.33.15_suppl.9004)

Horvat TZ, Adel NG, Dang TO, Momtaz P, Postow MA, Callahan MK, Carvajal RD, Dickson MA, D'Angelo SP, Woo KM, et al. 2015 Immune-related adverse events, need for systemic immunosuppression, and effects on survival and time to treatment failure in patients with melanoma treated with ipilimumab at memorial sloan kettering cancer center. Journal of Clinical Oncology 33 3193-3198. (doi:10.1200/JCO.2015.60.8448)

Ibrahim RA, Berman DM, DePril V, Humphrey RW, Chen T, Messina M, Chin KM, Liu HY, Bielefield M \& Hoos A 2011 Ipilimumab safety profile: summary of findings from completed trials in advanced melanoma. Journal of Clinical Oncology 29 (15 Suppl) 8583. (doi:10.1200/jco.2011.29.15_suppl.8583)
Iguchi H, Nogami N, Kozuki T, Matsumoto T, Tamura K, Yamamoto N, Shimomura A, Hoshino Y, Michibata Y, Nii M, et al. 2015 Phase I study to evaluate the safety and tolerability of MEDI4736, an antiprogrammed cell death ligand-1 (PD-L1) antibody, in Japanese patients with advanced solid tumors. Journal of Clinical Oncology 33 (15 Suppl) 3039. (doi:10.1200/jco.2015.33.15_suppl.3039)

Iwama S, De Remigis A, Callahan MK, Slovin SF, Wolchok JD \& Caturegli P 2014 Pituitary expression of CTLA-4 mediates hypophysitis secondary to administration of CTLA-4 blocking antibody. Science Translational Medicine 6 230ra245. (doi:10.1126/ scitranslmed.3008002)

Joshi MN, Whitelaw BC, Palomar MT, Wu Y \& Carroll PV 2016 Immune checkpoint inhibitor-related hypophysitis and endocrine dysfunction: clinical review. Clinical Endocrinology 85 331-339. (doi:10.1111/cen.13063)

Kazlauskaite R, Evans AT, Villabona CV, Abdu TA, Ambrosi B, Atkinson $\mathrm{AB}$, Choi $\mathrm{CH}$, Clayton $\mathrm{RN}$, Courtney $\mathrm{CH}$, Gonc EN, et al. 2008 Corticotropin tests for hypothalamic-pituitary-adrenal insufficiency: a metaanalysis. Journal of Clinical Endocrinology and Metabolism 93 4245-4253. (doi:10.1210/jc.2008-0710)

Kelly K, Patel MR, Infante JR, Iannotti N, Nikolinakos P, Leach J, Wang D, Chandler JC, Jerusalem GHM, Gurtler JS, et al. 2015 Avelumab (MSB0010718C), an anti-PD-L1 antibody, in patients with metastatic or locally advanced solid tumors: assessment of safety and tolerability in a phase I, open-label expansion study. Journal of Clinical Oncology 33 (15 Suppl) 3044. (doi:10.1200/jco.2015.33.15_ suppl.3044)

Kindler HL, Scherpereel A, Calabrò L, Aerts J, Perez SC, Bearz A, Nackaerts K, Fennell DA, Kowalski D, Tsao AS, et al. 2016 Tremelimumab as second- or third-line treatment of unresectable malignant mesothelioma (MM): results from the global, doubleblind, placebo-controlled determine study. Journal of Clinical Oncology 34 (15 Suppl) 8502. (doi:10.1200/JCO.2016.34.15_ suppl.8502)

Kirkwood JM, Lorigan P, Hersey P, Hauschild A, Robert C, McDermott D, Marshall MA, Gomez-Navarro J, Liang JQ \& Bulanhagui CA 2010 Phase II trial of tremelimumab (CP-675,206) in patients with advanced refractory or relapsed melanoma. Clinical Cancer Research 16 1042-1048. (doi:10.1158/1078-0432.CCR-09-2033)

Kitabchi AE, Umpierrez GE, Miles JM \& Fisher JN 2009 Hyperglycemic crises in adult patients with diabetes. Diabetes Care 32 1335-1343. (doi:10.2337/dc09-9032)

Klocke K, Sakaguchi S, Holmdahl R \& Wing K 2016 Induction of autoimmune disease by deletion of CTLA-4 in mice in adulthood. PNAS 113 E2383-E2392. (doi:10.1073/pnas.1603892113)

Ku GY, Yuan J, Page DB, Schroeder SE, Panageas KS, Carvajal RD, Chapman PB, Schwartz GK, Allison JP \& Wolchok JD 2010 Singleinstitution experience with ipilimumab in advanced melanoma patients in the compassionate use setting: lymphocyte count after 2 doses correlates with survival. Cancer 116 1767-1775. (doi:10.1002/ cncr.24951)

Kuehn HS, Ouyang W, Lo B, Deenick EK, Niemela JE, Avery DT, Schickel JN, Tran DQ, Stoddard J, Zhang Y, et al. 2014 Immune dysregulation in human subjects with heterozygous germline mutations in CTLA4. Science 345 1623-1627. (doi:10.1126/ science.1255904)

Kumar V, Chaudhary N, Garg M, Floudas CS, Soni P \& Chandra AB 2017 Current diagnosis and management of immune related adverse events (irAEs) induced by immune checkpoint inhibitor therapy. Frontiers in Pharmacology 8 49. (doi:10.3389/fphar.2017.00049)

Kwon ED, Drake CG, Scher HI, Fizazi K, Bossi A, van den Eertwegh AJ, Krainer M, Houede N, Santos R, Mahammedi H, et al. 2014 Ipilimumab versus placebo after radiotherapy in patientswith metastatic castration-resistant prostate cancer that had progressed after docetaxel chemotherapy (CA184-043): a multicentre,
(C) 2018 Society for Endocrinology Printed in Great Britain
Published by Bioscientifica Ltd 
randomised, double-blind, phase 3 trial. Lancet Oncology 15 700-712. (doi:10.1016/S1470-2045(14)70189-5)

Larkin J, Chiarion-Sileni V, Gonzalez R, Grob JJ, Cowey CL, Lao CD, Schadendorf D, Dummer R, Smylie M, Rutkowski P, et al. 2015 Combined nivolumab and ipilimumab or monotherapy in untreated melanoma. New England Journal of Medicine 373 23-34. (doi:10.1056/ NEJMoa1504030)

Latchman Y, Wood CR, Chernova T, Chaudhary D, Borde M, Chernova I, Iwai Y, Long AJ, Brown JA, Nunes R, et al. 2001 PD-L2 is a second ligand for PD-1 and inhibits T cell activation. Nature Immunology 2 261-268. (doi:10.1038/85330)

Laurent S, Queirolo P, Boero S, Salvi S, Piccioli P, Boccardo S, Minghelli S, Morabito A, Fontana V, Pietra G, et al. 2013 The engagement of CTLA- 4 on primary melanoma cell lines induces antibody-dependent cellular cytotoxicity and TNF- $\alpha$ production. Journal of Translational Medicine 11 108. (doi:10.1186/1479-587611-108)

Le DT, Uram JN, Wang H, Bartlett BR, Kemberling H, Eyring AD, Skora AD, Luber BS, Azad NS, Laheru D, et al. 2015 PD-1 blockade in tumors with mismatch-repair deficiency. New England Journal of Medicine 372 2509-2520. (doi:10.1056/NEJMoa1500596)

Lo JA, Fisher DE \& Flaherty KT 2015 Prognostic significance of cutaneous adverse events associated with pembrolizumab therapy. JAMA Oncology 1 1340-1341. (doi:10.1001/jamaoncol.2015.2274)

Lu J, Lee-Gabel L, Nadeau MC, Ferencz TM \& Soefje SA 2015 Clinical evaluation of compounds targeting PD-1/PD-L1 pathway for cancer immunotherapy. Journal of Oncology Pharmacy Practice 21 451-467. (doi:10.1177/1078155214538087)

Lutzky J, Antonia SJ, Blake-Haskins A, Li X, Robbins PB, Shalabi AM, Vasselli J, Ibrahim RA, Khleif S \& Segal NH 2014 A phase 1 study of MEDI4736, an anti-PD-L1 antibody, in patients with advanced solid tumors. Journal of Clinical Oncology 32 (15 Suppl) 3001 (doi:10.1200/ jco.2014.32.15_suppl.3001)

Lynch TJ, Bondarenko I, Luft A, Serwatowski P, Barlesi F, Chacko R, Sebastian M, Neal J, Lu H, Cuillerot JM, et al. 2012 Ipilimumab in combination with paclitaxel and carboplatin as first-line treatment in stage IIIB/IV non-small-cell lung cancer: results from a randomized, double-blind, multicenter phase II study. Journal of Clinical Oncology 30 2046-2054. (doi:10.1200/JCO.2011.38.4032)

Maker AV, Yang JC, Sherry RM, Topalian SL, Kammula US, Royal RE, Hughes M, Yellin MJ, Haworth LR, Levy C, et al. 2006 Intrapatient dose escalation of anti-CTLA-4 antibody in patients with metastatic melanoma. Journal of Immunotherapy 29 455-463. (doi:10.1097/01. cji.0000208259.73167.58)

Margolin K, Ernstoff MS, Hamid O, Lawrence D, McDermott D, Puzanov I, Wolchok JD, Clark JI, Sznol M, Logan TF, et al. 2012 Ipilimumab in patients with melanoma and brain metastases: an open-label, phase 2 trial. Lancet Oncology 13 459-465. (doi:10.1016/ S1470-2045(12)70090-6)

McElnea E, Ní Mhéalóid A, Moran S, Kelly R \& Fulcher T 2014 Thyroidlike ophthalmopathy in a euthyroid patient receiving Ipilimumab. Orbit 33 424-427. (doi:10.3109/01676830.2014.949792)

Michaelsen TE, Garred P \& Aase A 1991 Human IgG subclass pattern of inducing complement-mediated cytolysis depends on antigen concentration and to a lesser extent on epitope patchiness, antibody affinity and complement concentration. European Journal of Immunology 21 11-16. (doi:10.1002/eji.1830210103)

Michot JM, Bigenwald C, Champiat S, Collins M, Carbonnel F, PostelVinay S, Berdelou A, Varga A, Bahleda R, Hollebecque A, et al. 2016 Immune-related adverse events with immune checkpoint blockade: a comprehensive review. European Journal of Cancer $\mathbf{5 4}$ 139-148. (doi:10.1016/j.ejca.2015.11.016)

Min L \& Hodi FS 2014 Anti-PD1 following ipilimumab for mucosal melanoma: durable tumor response associated with severe hypothyroidism and rhabdomyolysis. Cancer Immunology Research 2 15-18. (doi:10.1158/2326-6066.CIR-13-0146)
Min L, Vaidya A \& Becker C 2011 Thyroid autoimmunity and ophthalmopathy related to melanoma biological therapy. European Journal of Endocrinology 164 303-307. (doi:10.1530/EJE-10-0833)

Min L, Hodi FS, Giobbie-Hurder A, Ott PA, Luke JJ, Donahue H, Davis M, Carroll RS \& Kaiser UB 2015 Systemic high-dose corticosteroid treatment does not improve the outcome of ipilimumab-related hypophysitis: a retrospective cohort study. Clinical Cancer Research 21 749-755. (doi:10.1158/1078-0432.CCR14-2353)

Mitchell AL, Cordell HJ, Soemedi R, Owen K, Skinningsrud B, Wolff AB, Undlien D, Husebye E \& Pearce SH 2009 Programmed death ligand 1 (PD-L1) gene variants contribute to autoimmune Addison's disease and Graves' disease susceptibility. Journal of Clinical Endocrinology and Metabolism 94 5139-5145. (doi:10.1210/jc.2009-1404)

Motzer RJ, Rini BI, McDermott DF, Redman BG, Kuzel TM, Harrison MR, Vaishampayan UN, Drabkin HA, George S, Logan TF, et al. 2015 Nivolumab for metastatic renal cell carcinoma: results of a randomized phase II trial. Journal of Clinical Oncology 33 1430-1437. (doi:10.1200/JCO.2014.59.0703)

Nanda R, Chow LQ, Dees EC, Berger R, Gupta S, Geva R, Pusztai L, Pathiraja K, Aktan G, Cheng JD, et al. 2016 Pembrolizumab in patients with advanced triple-negative breast cancer: phase $\mathrm{Ib}$ KEYNOTE-012 Study. Journal of Clinical Oncology 34 2460-2467. (doi:10.1200/JCO.2015.64.8931)

Nishio M, Hida T, Nakagawa K, Sakai H, Nogami N, Atagi S, Takahashi T, Nokihara H, Saka H, Takenoyama M, et al. 2015 Phase II studies of nivolumab (anti-PD-1, BMS-936558, ONO-4538) in patients with advanced squamous (sq) or nonsquamous (non-sq) non-small cell lung cancer (NSCLC). Journal of Clinical Oncology 33 (15 Suppl) 8027. (doi:10.1200/jco.2015.33.15_suppl.8027)

O'Day SJ, Maio M, Chiarion-Sileni V, Gajewski TF, Pehamberger H, Bondarenko IN, Queirolo P, Lundgren L, Mikhailov S, Roman L, et al. 2010 Efficacy and safety of ipilimumab monotherapy in patients with pretreated advanced melanoma: a multicenter single-arm phaseII study. Annals of Oncology 21 1712-1717. (doi:10.1093/ annonc/mdq013)

O'Donnell PH, Plimack ER, Bellmunt J, Berger R, Montgomery RB, Heath K, Dolled-Filhart M, Pathiraja K, Gause CK, Cheng JD, et al. 2015 Journal of Clinical Oncology 33 (7 Suppl) 296. (doi:10.1200/ jco.2015.33.7_suppl.296)

Ott PA, Fernandez MEE, Hiret S, Kim DW, Moss RA, Winser T, Yuan S, Cheng JD, Piperdi B \& Mehnert JM 2015 Pembrolizumab (MK-3475) in patients (pts) with extensive-stage small cell lung cancer (SCLC): preliminary safety and efficacy results from KEYNOTE-028. Journal of Clinical Oncology 33 (15 Suppl) 7502. (doi:10.1200/jco.2015.33.15_ suppl.7502)

Orlov S, Salari F, Kashat L \& Walfish PG 2015 Induction of painless thyroiditis in patients receiving programmed death 1 receptor immunotherapy for metastatic malignancies. Journal of Clinical Endocrinology and Metabolism 100 1738-1741. (doi:10.1210/jc.20144560)

Ospina NS, Al Nofal A, Bancos I, Javed A, Benkhadra K, Kapoor E, Lteif AN, Natt N \& Murad MH 2016 ACTH stimulation tests for the diagnosis of adrenal insufficiency: systematic review and metaanalysis. Journal of Clinical Endocrinology and Metabolism 101 427-434. (doi:10.1210/jc.2015-1700)

Patnaik A, Socinski MA, Gubens MA, Gandhi L, Stevenson J, Bachman RD, Bourque J, Ge JY, Im E \& Gadgeel SM 2015 Phase 1 study of pembrolizumab (pembro; MK-3475) plus ipilimumab (IPI) as second-line therapy for advanced non-small cell lung cancer (NSCLC): KEYNOTE-021 cohort D. Journal of Clinical Oncology 33 (15 Suppl) 8011. (doi:10.1200/jco.2015.33.15_suppl.8011)

Paz-Ares L, Horn L, Borghaei H, Spigel DR, Steins M, Ready N, Chow LQM, Vokes EE, Felip E, Holgado E, et al. 2015 Phase III, randomized trial (CheckMate 057) of nivolumab (NIVO) versus docetaxel (DOC) in advanced non-squamous cell (non-SQ) non- 
small cell lung cancer (NSCLC). Journal of Clinical Oncology 33 (18 Suppl) LBA109. (doi:10.1200/jco.2015.33.18_suppl.lba109)

Petrylak DP, Powles T, Bellmunt J, Braiteh FS, Loriot Y, Zambrano CC, Burris HA, Kim JW, Teng SM, Bruey JM, et al. 2015 A phase Ia study of MPDL3280A (anti-PDL1): updated response and survival data in urothelial bladder cancer (UBC). Journal of Clinical Oncology 33 (15 Suppl) 4501.

Phan GQ, Yang JC, Sherry RM, Hwu P, Topalian SL, Schwartzentruber DJ, Restifo NP, Haworth LR, Seipp CA, Freezer LJ, et al. 2003 Cancer regression and autoimmunity induced by cytotoxic $\mathrm{T}$ lymphocyteassociated antigen 4 blockade in patients with metastatic melanoma. PNAS 100 8372-8377. (doi:10.1073/pnas.1533209100)

Pillai R, Behera M, Owonikoko T, Kamphorst A, Pakkala S, Belani C, Khuri F, Ahmed R \& Ramalingam S 2016 OA03.06 evaluation of toxicity profile of PD-1 versus PD-L1 inhibitors in non-small cell lung cancer (NSCLC). Journal of Thoracic Oncology 12 S253-S254. (doi:10.1016/j.jtho.2016.11.242)

Postow MA, Callahan MK, Barker CA, Yamada Y, Yuan J, Kitano S, Mu Z, Rasalan T, Adamow M, Ritter E, et al. 2012 Immunologic correlates of the abscopal effect in a patient with melanoma. New England Journal of Medicine 366 925-931. (doi:10.1056/NEJMoa1112824)

Postow MA, Chesney J, Pavlick AC, Robert C, Grossmann K, McDermott D, Linette GP, Meyer N, Giguere JK, Agarwala SS, et al. 2015 Nivolumab and ipilimumab versus ipilimumab in untreated melanoma. New England Journal of Medicine 372 2006-2017. (doi:10.1056/NEJMoa1414428)

Powles T, Eder JP, Fine GD, Braiteh FS, Loriot Y, Cruz C, Bellmunt J, Burris HA, Petrylak DP, Teng SL, et al. 2014 MPDL3280A (anti-PD-L1) treatment leads to clinical activity in metastatic bladder cancer. Nature 515 558-562. (doi:10.1038/nature13904)

Ralph C, Elkord E, Burt DJ, O'Dwyer JF, Austin EB, Stern PL, Hawkins RE \& Thistlethwaite FC 2010 Modulation of lymphocyte regulation for cancer therapy: a phaseII trial of tremelimumab in advanced gastric and esophageal adenocarcinoma. Clinical Cancer Research 16 1662-1672. (doi:10.1158/1078-0432.CCR-09-2870)

Reck M, Bondarenko I, Luft A, Serwatowski P, Barlesi F, Chacko R, Sebastian M, Lu H, Cuillerot JM \& Lynch TJ 2013 Ipilimumab in combination with paclitaxel and carboplatin as first-line therapy in extensive-disease-small-cell lung cancer: results from a randomized, double-blind, multicenter phase 2 trial. Annals of Oncology 24 75-83. (doi:10.1093/annonc/mds213)

Reck M, Rodríguez-Abreu D, Robinson AG, Hui R, Csőszi T, Fülöp A, Gottfried M, Peled N, Tafreshi A, Cuffe S, et al. 2016 Pembrolizumab versus chemotherapy for PD-L1-positive non-small-cell lung cancer. New England Journal of Medicine 375 1823-1833. (doi:10.1056/ NEJMoa1606774)

Ribas A, Camacho LH, Lopez-Berestein G, Pavlov D, Bulanhagui CA, Millham R, Comin-Anduix B, Reuben JM, Seja E, Parker CA, et al. 2005 Antitumor activity in melanoma and anti-self responses in a phase I trial with the anti-cytotoxic T lymphocyte-associated antigen 4 monoclonal antibody CP-675,206. Journal of Clinical Oncology 23 8968-8977. (doi:10.1200/JCO.2005.01.109)

Ribas A, Chesney JA, Gordon MS, Abernethy AP, Logan TF, Lawson DH, Chmielowksi B, Glaspy JA, Lewis K, Huang B, et al. 2012 Safety profile and pharmacokinetic analyses of the anti-CTLA4 antibody tremelimumab administered as a one hour infusion. Journal of Translational Medicine 10 236. (doi:10.1186/1479-5876-10-236)

Ribas A, Kefford R, Marshall MA, Punt CJ, Haanen JB, Marmol M, Garbe C, Gogas H, Schachter J, Linette G, et al. 2013 Phase III randomized clinical trial comparing tremelimumab with standard-ofcare chemotherapy in patients with advanced melanoma. Journal of Clinical Oncology 31 616-622. (doi:10.1200/JCO.2012.44.6112)

Ribas A, Puzanov I, Dummer R, Schadendorf D, Hamid O, Robert C, Hodi FS, Schachter J, Pavlick AC, Lewis KD, et al. 2015 Pembrolizumab versus investigator-choice chemotherapy for ipilimumab-refractory melanoma (KEYNOTE-002): a randomised, controlled, phase 2 trial. Lancet Oncology 16 908-918. (doi:10.1016/ S1470-2045(15)00083-2)

Ribas A, Hamid O, Daud A, Hodi FS, Wolchok JD, Kefford R, Joshua AM, Patnaik A, Hwu WJ, Weber JS, et al. 2016 Association of pembrolizumab with tumor response and survival among patients with advanced melanoma. JAMA 315 1600-1609. (doi:10.1001/ jama.2016.4059)

Rizvi NA, Brahmer JR, Ou S-HI, Segal NH, Khleif S, Hwu W-J, Gutierrez M, Schoffski P, Hamid O, Weiss J, et al. 2015a Safety and clinical activity of MEDI4736, an anti-programmed cell death-ligand 1 (PD-L1) antibody, in patients with non-small cell lung cancer (NSCLC). Journal of Clinical Oncology 33 (15 Suppl) 8032 (doi:10.1200/jco.2015.33.15_suppl.8032)

Rizvi NA, Mazières J, Planchard D, Stinchcombe TE, Dy GK, Antonia SJ, Horn L, Lena H, Minenza E, Mennecier B, et al. 2015b Activity and safety of nivolumab, an anti-PD-1 immune checkpoint inhibitor, for patients with advanced, refractory squamous non-small-cell lung cancer (CheckMate 063): a phase 2, single-arm trial. Lancet Oncology 16 257-265. (doi:10.1016/S14702045(15)70054-9)

Robert C, Ribas A, Wolchok JD, Hodi FS, Hamid O, Kefford R, Weber JS, Joshua AM, Hwu WJ, Gangadhar TC, et al. 2014 Anti-programmeddeath-receptor-1 treatment with pembrolizumab in ipilimumabrefractory advanced melanoma: a randomised dose-comparison cohort of a phase 1 trial. Lancet 384 1109-1117. (doi:10.1016/S01406736(14)60958-2)

Robert C, Long GV, Brady B, Dutriaux C, Maio M, Mortier L, Hassel JC, Rutkowski P, McNeil C, Kalinka-Warzocha E, et al. 2015a Nivolumab in previously untreated melanoma without BRAF mutation. New England Journal of Medicine 372 320-330. (doi:10.1056/ NEJMoa1412082)

Robert C, Schachter J, Long GV, Arance A, Grob JJ, Mortier L, Daud A, Carlino MS, McNeil C, Lotem M, et al. 2015b Pembrolizumab versus ipilimumab in advanced melanoma. New England Journal of Medicine 372 2521-2532. (doi:10.1056/NEJMoa1503093)

Romano E, Kusio-Kobialka M, Foukas PG, Baumgaertner P, Meyer C, Ballabeni P, Michielin O, Weide B, Romero P \& Speiser DE 2015 Ipilimumab-dependent cell-mediated cytotoxicity of regulatory $\mathrm{T}$ cells ex vivo by nonclassical monocytes in melanoma patients. PNAS A112 6140-6145. (doi:10.1073/pnas.1417320112)

Rosenberg JE, Hoffman-Censits J, Powles T, van der Heijden MS, Balar AV, Necchi A, Dawson N, O’Donnell PH, Balmanoukian A, Loriot Y, et al. 2016 Atezolizumab in patients with locally advanced and metastatic urothelial carcinoma who have progressed following treatment with platinum-based chemotherapy: a single-arm, multicentre, phase 2 trial. Lancet 387 1909-1920. (doi:10.1016/ S0140-6736(16)00561-4)

Royal RE, Levy C, Turner K, Mathur A, Hughes M, Kammula US, Sherry RM, Topalian SL, Yang JC, Lowy I, et al. 2010 Phase 2 trial of single agent Ipilimumab (anti-CTLA-4) for locallyadvanced or metastatic pancreatic adenocarcinoma. Journal of Immunotherapy $\mathbf{3 3}$ 828-833. (doi:10.1097/CJI.0b013e3181eec14c)

Rozali EN, Hato SV, Robinson BW, Lake RA \& Lesterhuis WJ 2012 Programmed death ligand 2 in cancer-induced immune suppression. Clinical and Developmental Immunology 20128. (doi:10.1155/2012/656340)

Ryder M, Callahan M, Postow MA, Wolchok J \& Fagin JA 2014 Endocrine-related adverse events following ipilimumab in patients with advanced melanoma: a comprehensive retrospective review from a single institution. Endocrine-Related Cancer 21 371-381. (doi:10.1530/ERC-13-0499)

Sangro B, Gomez-Martin C, de la Mata M, Iñarrairaegui M, Garralda E, Barrera P, Riezu-Boj JI, Larrea E, Alfaro C, Sarobe P, et al. 2013 A clinical trial of CTLA-4 blockade with tremelimumab in patients with hepatocellular carcinoma and chronic hepatitis C. Journal of Hepatology 59 81-88. (doi:10.1016/j.jhep.2013.02.022)
○ 2018 Society for Endocrinology Printed in Great Britain 
Sarnaik AA, Yu B, Yu D, Morelli D, Hall M, Bogle D, Yan L, Targan S, Solomon J, Nichol G, et al. 2011 Extended dose ipilimumab with a peptide vaccine: immune correlates associated with clinical benefit in patients with resected high-risk stage IIIc/IV melanoma. Clinical Cancer Research 17 896-906. (doi:10.1158/1078-0432.CCR-10-2463)

Schubert D, Bode C, Kenefeck R, Hou TZ, Wing JB, Kennedy A, Bulashevska A, Petersen BS, Schäffer AA, Grüning BA, et al. 2014 Autosomal dominant immune dysregulation syndrome in humans with CTLA4 mutations. Nature Medicine 20 1410-1416. (doi:10.1038/ nm.3746)

Segal NH, Antonia SJ, Brahmer JR, Maio M, Blake-Haskins A, Li X, Vasselli J, Ibrahim RA, Lutzky J \& Khleif S 2014 Preliminary data from a multi-arm expansion study of MEDI4736, an anti-PD-L1 antibody. Journal of Clinical Oncology 32 (15 Suppl) 3002. (doi:10.1200/jco.2014.32.15_suppl.3002)

Segal NH, Ou SHI, Balmanoukian AS, Massarelli E, Brahmer JR, Weiss J, Schoffski P, Antonia SJ, Massard C, Zandberg DP, et al. 2016 Updated safety and efficacy of durvalumab (MEDI4736), an anti-PD-L 1 antibody, in patients from a squamous cell carcinoma of the head and neck (SCCHN) expansion cohort. Annals of Oncology 279490. (doi:10.1093/annonc/mdw376)

Seiwert TY, Burtness B, Mehra R, Weiss J, Berger R, Eder JP, Heath K, McClanahan T, Lunceford J, Gause C, et al. 2016 Safety and clinical activity of pembrolizumab for treatment of recurrent or metastatic squamous cell carcinoma of the head and neck (KEYNOTE-012): an open-label, multicentre, phase 1b trial. Lancet Oncology 17 956-965. (doi:10.1016/S1470-2045(16)30066-3)

Shahabi V, Postow MA, Tuck D \& Wolchok JD 2015 Immune-priming of the tumor microenvironment by radiotherapy: rationale for combination with immunotherapy to improve anticancer efficacy. American Journal of Clinical Oncology 38 90-97. (doi:10.1097/ COC.0b013e3182868ec8)

Shitara K, Yamada Y, Yoh K, Naito Y, Iwasa S, Yamamoto N, Heydebreck Av, Achiwa H \& Doi T 2015 Phase I, open-label, multiascending dose trial of avelumab (MSB0010718C), an anti-PD-L1 monoclonal antibody, in Japanese patients with advanced solid tumors. Journal of Clinical Oncology 33 (15 Suppl) 3023. (doi:10.1200/ jco.2015.33.15_suppl.3023)

Spigel DR, Gettinger SN, Horn L, Herbst RS, Gandhi L, Gordon MS, Cruz C, Conkling P, Cassier PA, Antonia SJ, et al. 2013 Clinical activity, safety, and biomarkers of MPDL3280A, an engineered PD-L1 antibody in patients with locally advanced or metastatic non-small cell lung cancer (NSCLC). Journal of Clinical Oncology 31 (15 Suppl) 8008. (doi:10.1200/jco.2013.31.15_suppl.8008)

Slovin SF, Higano CS, Hamid O, Tejwani S, Harzstark A, Alumkal JJ, Scher HI, Chin K, Gagnier P, McHenry MB, et al. 2013 Ipilimumab alone or in combination with radiotherapy in metastatic castrationresistant prostate cancer: results from an open-label, multicenter phase I/II study. Annals of Oncology 24 1813-1821. (doi:10.1093/ annonc/mdt107)

Spira AI, Park K, Mazières J, Vansteenkiste JF, Rittmeyer A, Ballinger M, Waterkamp D, Kowanetz M, Mokatrin A \& Fehrenbacher L 2015 Efficacy, safety and predictive biomarker results from a randomized phase II study comparing MPDL3280A vs docetaxel in 2L/3L NSCLC (POPLAR). Journal of Clinical Oncology 33 (15 Suppl) 8010 (doi:10.1200/jco.2015.33.15_suppl.8010)

Stamell EF, Wolchok JD, Gnjatic S, Lee NY \& Brownell I 2013 The abscopal effect associated with a systemic anti-melanoma immune response. International Journal of Radiation Oncology, Biology, Physics 85 293-295. (doi:10.1016/j.ijrobp.2012.03.017)

Streilein JW 2003 Ocular immune privilege: therapeutic opportunities from an experiment of nature. Nature Reviews Immunology 3 879-889. (doi:10.1038/nri1224)

Tarhini AA, Cherian J, Moschos SJ, Tawbi HA, Shuai Y, Gooding WE, Sander C \& Kirkwood JM 2012 Safety and efficacy of combination immunotherapy with interferon alfa-2b and tremelimumab in http://erc.endocrinology-journals.org

DOI: $10.1530 /$ ERC-17-0358
(C) 2018 Society for Endocrinology Printed in Great Britain patients with stage IV melanoma. Journal of Clinical Oncology 30 322-328. (doi:10.1200/JCO.2011.37.5394)

Teulings H-E, Limpens J, Jansen SN, Zwinderman AH, Reitsma JB, Spuls PI \& Luiten RM 2015 Vitiligo-like depigmentation in patients with stage III-IV melanoma receiving immunotherapy and its association with survival: a systematic review and meta-analysis. Journal of Clinical Oncology 33 773-781. (doi:10.1200/ JCO.2014.57.4756)

Topalian SL, Hodi FS, Brahmer JR, Gettinger SN, Smith DC, McDermott DF, Powderly JD, Carvajal RD, Sosman JA, Atkins MB, et al. 2012 Safety, activity, and immune correlates of anti-PD-1 antibody in cancer. New England Journal of Medicine 366 2443-2454 (doi:10.1056/NEJMoa1200690)

Topalian SL, Sznol M, McDermott DF, Kluger HM, Carvajal RD, Sharfman WH, Brahmer JR, Lawrence DP, Atkins MB, Powderly JD, et al. 2014 Survival, durable tumor remission, and long-term safety in patients with advanced melanoma receiving nivolumab. Journal of Clinical Oncology 32 1020-1030. (doi:10.1200/JCO.2013.53.0105)

Ueda H, Howson JMM, Esposito L, Heward J, Snook, Chamberlain G, Rainbow DB, Hunter KMD, Smith AN, Di Genova G, et al. 2003 Association of the T-cell regulatory gene CTLA4 with susceptibility to autoimmune disease. Nature 423 506-511. (doi:10.1038/ nature01621)

van der Hiel B, Blank CU, Haanen JB \& Stokkel MP 2013 Detection of early onset of hypophysitis by (18)F-FDG PET-CT in a patient with advanced stage melanoma treated with ipilimumab. Clinical Nuclear Medicine 38 e182-e184. (doi:10.1097/RLU.0b013e3182639765)

Varga A, Piha-Paul SA, Ott PA, Mehnert JM, Berton-Rigaud D, Johnson EA, Cheng JD, Yuan S, Rubin EH \& Matei DE 2015 Antitumor activity and safety of pembrolizumab in patients (pts) with PD-L1 positive advanced ovarian cancer: Interim results from a phase Ib study. Journal of Clinical Oncology 33 (15 Suppl) 5510. (doi:10.1200/jco.2015.33.15_suppl.5510)

Vidarsson G, Dekkers G \& Rispens T 2014 IgG subclasses and allotypes: from structure to effector functions. Frontiers in Immunology 5520. (doi:10.3389/fimmu.2014.00520)

Weber J 2009 Ipilimumab: controversies in its development, utility and autoimmune adverse events. Cancer Immunology, Immunotherapy 58 823-830. (doi:10.1007/s00262-008-0653-8)

Weber J, O’Day S, Urba W, Powderly J, Nichol G, Yellin M, Snively J \& Hersh E 2008 Phase I/II study of ipilimumab for patients with metastaticmelanoma. Journal of Clinical Oncology 26 5950-5956. (doi:10.1200/JCO.2008.16.1927)

Weber J, Thompson JA, Hamid O, Minor D, Amin A, Ron I, Ridolfi R, Assi H, Maraveyas A, Berman D, et al. 2009 A randomized, doubleblind, placebo-controlled, phase II study comparing the tolerability and efficacy of ipilimumabadministered with or without prophylactic budesonide in patients with unresectable stage III or IV melanoma. Clinical Cancer Research 15 5591-5598. (doi:10.1158/1078-0432.CCR-09-1024)

Weber JS, Kudchadkar RR, Yu B, Gallenstein D, Horak CE, Inzunza HD, Zhao X, Martinez AJ, Wang W, Gibney G, et al. 2013 Safety, efficacy, and biomarkers of nivolumab with vaccine in ipilimumab-refractory or -naive melanoma. Journal of Clinical Oncology 31 4311-4318. (doi:10.1200/JCO.2013.51.4802)

Weber JS, D'Angelo SP, Minor D, Hodi FS, Gutzmer R, Neyns B, Hoeller C, Khushalani NI, Miller WH, Lao CD, et al. $2015 a$ Nivolumab versus chemotherapy in patients with advanced melanoma who progressed after anti-CTLA-4 treatment (CheckMate 037): a randomised, controlled, open-label, phase 3 trial. Lancet Oncology 16 375-384. (doi:10.1016/S1470-2045(15)70076-8)

Weber JS, Gibney GT, Yu B, Cheng PY, Martinez AJ, Kroeger J, Freed J, Richards A, Zhao X \& Schell MJ 2015b Survival, biomarker, and toxicity analysis of nivolumab (NIVO) in patients that progressed on ipilimumab (IPI). Journal of Clinical Oncology 33 (15 Suppl) 9055. (doi:10.1200/jco.2015.33.15_suppl.9055) 
Weber J, Mandala M, Del Vecchio M, Gogas HJ, Arance AM, Cowey CL, Dalle S, Schenker M, Chiarion-Sileni V, Marquez-Rodas I, et al. 2017 Adjuvant nivolumab versus ipilimumab in resected stage III or IV melanoma. New England Journal of Medicine [in press]. (doi:10.1056/ NEJMoa1709030)

Win MA, Thein KZ, Qdaisat A \& Yeung SJ 2017 Acute symptomatic hypocalcemia from immune checkpoint therapy-induced hypoparathyroidism. American Journal of Emergency Medicine 351039. e5-1039.e7. (doi:10.1016/j.ajem.2017.02.048)

Wolchok JD, Neyns B, Linette G, Negrier S, Lutzky J, Thomas L, Waterfield W, Schadendorf D, Smylie M, Guthrie T, et al. 2010 Ipilimumab monotherapy in patients with pretreated advanced melanoma: a randomised, doubleblind, multicentre, phase 2, dose-ranging study. Lancet Oncology 11 155164. (doi:10.1016/S1470-2045(09)70334-1)

Wolchok JD, Kluger H, Callahan MK, Postow MA, Rizvi NA, Lesokhin AM, Segal NH, Ariyan CE, Gordon RA, Reed K, et al. 2013 Nivolumab plus ipilimumab in advanced melanoma. New England Journal of Medicine 369 122-133. (doi:10.1056/NEJMoa1302369)
Yamada Y, Nishina T, Iwasa S, Shitara K, Muro K, Esaki T, Hironaka S, Yamaguchi K, Machida N, Satoh T, et al. 2015 A phase I dose expansion trial of avelumab (MSB0010718C), an anti-PD-L1 antibody, in Japanese patients with advanced gastric cancer. Journal of Clinical Oncology 33 (15 Suppl) 4047. (doi:10.1200/jco.2015.33.15 suppl.4047)

Yang JC, Hughes M, Kammula U, Royal R, Sherry RM, Topalian SL, Suri KB, Levy C, Allen T, Mavroukakis S, et al. 2007 Ipilimumab (anti-CTLA4 antibody) causes regression of metastatic renal cell cancer associated with enteritis and hypophysitis. Journal of Immunotherapy 30 825-830. (doi:10.1097/CJI.0b013e318156e47e)

Yeh OL \& Francis CE 2015 Ipilimumab-associated bilateral optic neuropathy. Journal of Neuro-Ophthalmology 35 144-147. (doi:10.1097/WNO.0000000000000217)

Yu C, Chopra IJ \& Ha E 2015 A novel melanoma therapy stirs up a storm: ipilimumab-induced thyrotoxicosis. Endocrinology, Diabetes and Metabolism Case Reports 2015 article ID 14-0092. (doi:10.1530/ EDM-14-0092)

Received in final form 5 October 2017

Accepted 12 October 2017

Accepted Preprint published online 12 October 2017
Published by Bioscientifica Ltd. 